\title{
STUDIES OF MAXILLARY NERVE BLOCK AT FORAMEN ROTUNDUM
}

\author{
$\mathrm{By}$
}

\author{
A. NAITŌ
}

From the Department of Oto-Rhino-Laryngology, School of Medicine. Keio-Gijuku University, (Director: Prof. T. Nishihata)

A new method of maxillary block was devised improving ostwalt's method which has the highest rate of success in reaching to pterygopalatine fossa, while its rate in reaching to'the canalis rotundus is low. Distance between the lowest point on the inferior margin of the orbit and the biting surface of the second false molar of the upper jaw was measured and this was suggested as the distance of needle insertion. The needle is inserted at the possible nearest point to the pterygopalatine fossa on the posterior margin of the tuber maxillae in the oral cavity. Then the point of the needle is inserted exactly into the pterygopalatine fossa using specially devised needle. Thus the maxillary nerve is reached and then the direction of the needle is changed after Matas-Braun's or Sicher's method which have the high rate in reaching canalis rotundus. Thereby, in foramen rotundum, the block of the maxillary branch of the trigeminal nerve is given whithout danger or difficulty.

\section{上顎神経正円孔部伝達麻酔の研究}

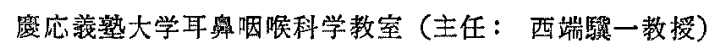

内 藤厚德

\begin{tabular}{|c|c|}
\hline & 次 \\
\hline 緒 & 曾 \\
\hline 各 & 論 \\
\hline 1 & 上顎神経径路（仮想）の解剖学的計測 \\
\hline$\llbracket$ & 巽蒚並びに正円管到達率より見たる Ostwalt法 \\
\hline III & $\begin{array}{l}\text { Ostwalt 法による翟简刺入のために頭蓋骨側面 } \\
\text { より見た刺入目栖 }\end{array}$ \\
\hline IV & $\begin{array}{l}\text { Ostwalt 法による潩富刺入のために頭蓋骨正面 } \\
\text { より見た正中面に対する刺入角度 }\end{array}$ \\
\hline V & 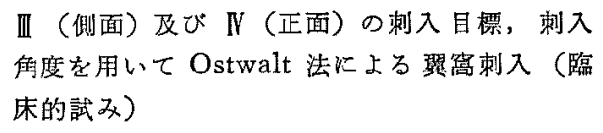 \\
\hline VI & 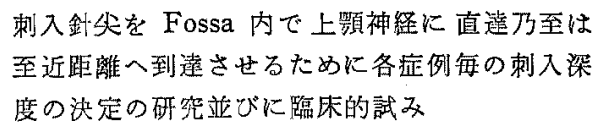 \\
\hline VI & $\begin{array}{l}\text { 私のOstwalt改良法により翼简に刺入せられた } \\
\text { 針尖を引き続き正円孔部へ澾せしめる方法 }\end{array}$ \\
\hline VII & 刺入力法 \\
\hline 考 & 按 \\
\hline 結 & 語 \\
\hline
\end{tabular}

\begin{abstract}
緒言
私は数年来上頍神経伝達麻醉法に就いて研究を行つて きた，その研究方法は従来発表された諸氏の方法と少し く異なり先ず解剖学的計測研究を行い，その結果を直ら に臨床的に追試し不満足な点を見出せば再び解剖学的に 再検討すると云う順序を繰り返えして飽く迄も正円孔部 麻酔法を最終目標として研究してきたるので最近に至り ほぶ所期の目的に適つた方法を案出したのでこつに報告 する次第である。

従来の諸研究者の文献を見るといずれる刺入深度や刺 入角度の統計学的平坛值を基にし首間とか対側頭頂結節 とか Foramen infraorbitale とかの比較的漠然とした Merkmalにより剌入を行つているが翼口蓋窝(以下翼藏 又はFossa とする）及びその附近の解剖学的複雑さを 考光ると $100 \%$ 乃至は $100 \%$ に近い磨酔効果を獲得する ことは実際に臨床的に追試してみると決して容易で性な い事が分る。この不明膫な刺入深度や刺入角度刺入目樏 をもつ之正確で分り易くしか子冬臨床例每に予知し得 る方法があるならば結果として当然绦酔成結は向上する であろうし，従来鬼艪困難視され勝らな上枵神経伝達麻 酔法は一般的に容易に行い得る筈である。
\end{abstract}




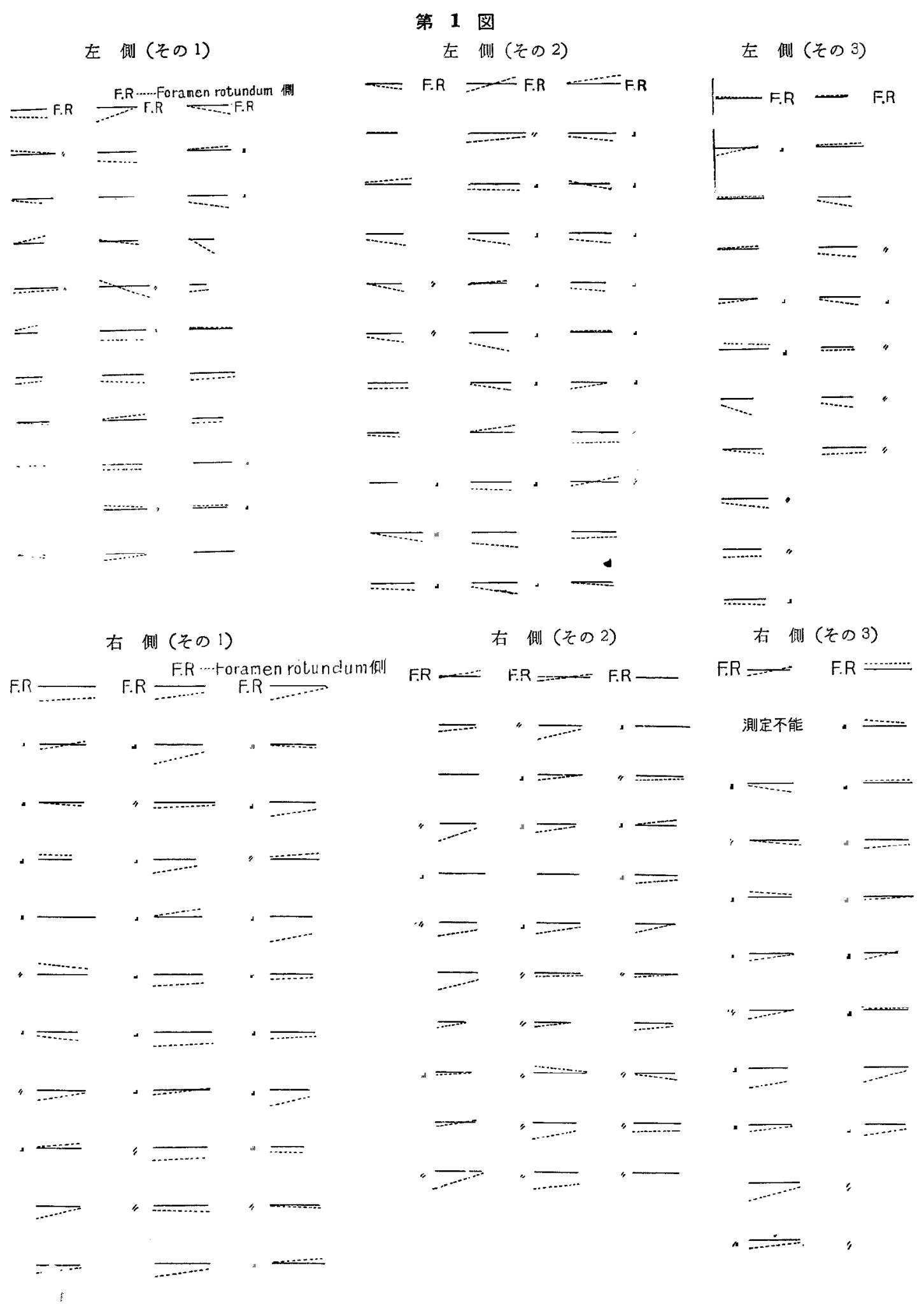




\section{各論}

\section{I 上顎神経径路 (仮想) の解剖学的計測}

先ず最初に顔面皮膚上より各臨床例毎に上顎神経の走 行径路を予知できれば麻酷施行時大いに役立つであろう 之考兄晒頭蓋骨 50 例, 100 側 (年令性別不問, 但し孚, 奻，小児の標本は除く以下同様）により次の如き計測を 試みた（第1困）この困に批いて実線は Foramen rotundum と眼罙内に和ける Canalis (od, Sulcus) infraorbitalis 入口部を直線的结んだ線の位置，叉点線は 両側の眼窠下縁最低点々一側の煩骨水平及び上行突起の なす隅㞣部との 3 点を含む平面の位置の高さを示すもの で（第 2 図）この実線及び点線が側面投影で検查総数の 1/2 強に扔いてほ心゙重なることが分る，この結果を臨床 的に用いて上顎米 7 番乃至 8 番より両側腿窠下緑最低点

\section{第 2 図}

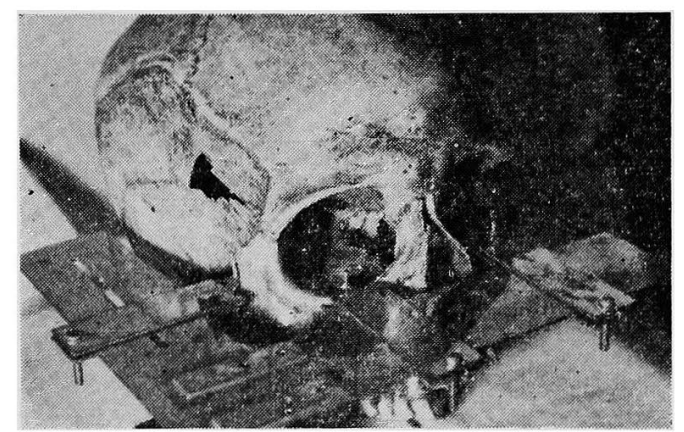

両側の眼窠下緑最低点と一側の煩骨水平及び上行 实起のなす隅角部との 3 点を含む平面を示す

と術側の煩骨水平及び上行突起のなす隅盾部との 3 点を 含さ平面に対乙側面より見て直角に正面よりは正中面に 対し鋭看をなすように口腔前庭で刺入を試みたが針尖が Incisura orbitalis inferior 飞入る場合中翼突起方向 (Fossa より後方) に向うものなど種々で上顎神経が分 枝を出す前の中枢部に淤ける伝達麻酔を必ずしも行兄ず 臨床的に効果的な麻酔を獲得するためにはどうしても刺 入針尖が毎常翼简内に確実に刺入されることの必要性が 分つた。

』翼䈑並びに正円管到達率より 見たる Ostwalt 法.

こつで従斥:の方法による刺入点を第 3 図に文晒頭蓋骨 の翼窩刺入率を野洨の交献より参照第 1 表に示す この 表を見ると Matas-Braun 法よりも Sicher 法更にBlumental 法（以上の方法では刺入点は翼窩より前方にな
第 3 図 従来の各研究者の刺入点

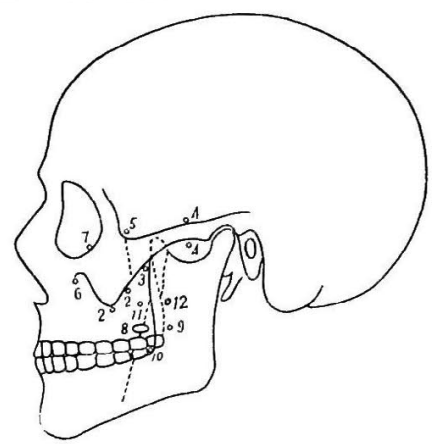

(1) Matas-Braun…刺入点, 煩骨上顎䋮合下端

(2) Sicher …刺入点, 煩骨水平上行突起のなす隅角 部より垂線を下しその煩骨下縁との交点と頑骨 上顕縫合下端との中点

(3) Blumenta1…刺入点, 下顎鳥潒突起々煩骨下縁 となす隅角部

(4) Offerhaus...刺入点, 烦骨弓上縁及び下緑の中 央部

(5) Payr …刺入点, 煩骨水平及び上行突起のなす偶 角部

(6) 斎藤 (寛) …刺入点, 上罘骨煩骨灾起根部直下

(7) Härtel...刺入点, 眼窠外縁と下縁との移行部

(8) Hofer …刺入点, 経大口蓋孔

(9) Ostwalt...刺入点, 第 3 大臼歯後方

(10) 野村 (俊五) …刺入点, 下顎骨体部と枝部との なす隅角部

(11) 野村第 2 法刺入点…頼骨上顎綖合下端々下顯骨 体部と枝部とのなす隅角部を結んだ線及び䫅骨 の下縁並びに下顎骨枝部前縁とに团まれた三角 部を設定するSicher 点より䫅骨上顎總合下端 一下影骨内隅角線に平行線を引き, Sicher点よ り $1.5 \mathrm{~cm}$ の所を刺入点とする

(19) 著者の刺入点

第 1 表 (その 1)

Matas-Braun 法による翼䨐刺入率（野村）

\begin{tabular}{|c|c|c|c|c|}
\hline & $\begin{array}{l}\text { 検 查 } \\
\text { 例 }\end{array}$ & $\begin{array}{l}\text { 制 } \\
\text { 例 } \\
\end{array}$ & $\begin{array}{l}\text { 標 } 4 \\
\text { 百分來 } \%\end{array}$ \\
\hline$\widehat{\delta}$ & $\begin{array}{l}\text { 左 } \\
\text { 右 }\end{array}$ & $\begin{array}{l}63 \\
63\end{array}$ & $\begin{array}{l}57 \\
55\end{array}$ & $\begin{array}{l}80.96 \\
87.31\end{array}$ \\
\hline q & $\begin{array}{l}\text { 左 } \\
\text { 右 }\end{array}$ & $\begin{array}{l}13 \\
13\end{array}$ & $\begin{array}{l}12 \\
12\end{array}$ & $\begin{array}{l}92.31 \\
92.31\end{array}$ \\
\hline
\end{tabular}

Sicher 法に上る翼简刺入蒂（野村）

\begin{tabular}{|c|c|c|c|c|}
\hline & & $\begin{array}{l}\text { 検 查 } \\
\text { 例 } \\
\end{array}$ & $\begin{array}{ll}\text { 刺 } & \text { 人 } \\
\text { 例 }\end{array}$ & $\begin{array}{l}\text { 㯪 } 4 \\
\text { 百分率 } \%\end{array}$ \\
\hline 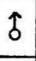 & $\begin{array}{l}\text { 左 } \\
\text { 右 }\end{array}$ & $\begin{array}{l}63 \\
63 \\
\end{array}$ & $\begin{array}{l}62 \\
61\end{array}$ & $\begin{array}{l}98.4 \\
98.38\end{array}$ \\
\hline 우 & 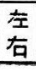 & $\begin{array}{l}13 \\
13 \\
\end{array}$ & $\begin{array}{l}12 \\
13 \\
\end{array}$ & $\begin{array}{c}92.3 \\
100\end{array}$ \\
\hline
\end{tabular}


Blumental 法に上る翼简刺入絮（野村）

\begin{tabular}{|c|c|c|c|c|}
\hline & 梌 龺 & 制 & $\begin{array}{l}\text { 孀本 } \\
\text { 百分率\% }\end{array}$ \\
\hline$\delta$ & $\begin{array}{l}\text { 左 } \\
\text { 右 }\end{array}$ & $\begin{array}{l}61 \\
60\end{array}$ & $\begin{array}{l}61 \\
59\end{array}$ & $\begin{array}{c}100 \\
96.7\end{array}$ \\
\hline 오 & $\begin{array}{l}\text { 左 } \\
\text { 右 }\end{array}$ & $\begin{array}{l}13 \\
13\end{array}$ & $\begin{array}{l}13 \\
13\end{array}$ & $\begin{array}{l}100 \\
100\end{array}$ \\
\hline
\end{tabular}

詐：。不成功 1 例は刺入点が Sicher 法に一致し たため不成功としたので本来ならば成功とし て良いものである（野村）

第 1 表 (その2)

煩咸弓下粶上りする Offerhaus 法 (野村)

\begin{tabular}{|c|c|c|c|c|}
\hline & & 検 龺 & \begin{tabular}{|ll} 
制 & $\lambda$ \\
列
\end{tabular} & 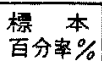 \\
\hline$\xi$ & 左 & $\begin{array}{l}67 \\
60\end{array}$ & $\begin{array}{l}59 \\
58\end{array}$ & \begin{tabular}{|l|}
96.7 \\
967
\end{tabular} \\
\hline ㅇ & $\begin{array}{l}\text { 左 } \\
\text { 后 }\end{array}$ & $\begin{array}{l}13 \\
13\end{array}$ & $\begin{array}{l}12 \\
11\end{array}$ & $\begin{array}{l}92.3 \\
84.6\end{array}$ \\
\hline
\end{tabular}

Ostwalt 法による翼窝刺入率 (内藤)

\begin{tabular}{|c|c|c|c|}
\hline & 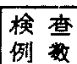 & $\begin{array}{ll}\text { 帮 } & \lambda \\
\text { 例 }\end{array}$ & 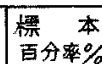 \\
\hline 性别不䦓 & 100 & 100 & 100 \\
\hline
\end{tabular}

註：乳，幼，小胃の標本は除外せり

る) Offerhaus 法（刺入点は翼窝より後うにはなる）と側

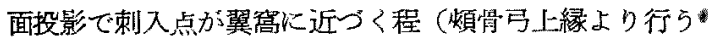
Offerhaus 法及び煩骨水平突起と同上行帘起とのなす隅 角部より行う Payr 法はこっでは除外する) 刺入率が良 くなる事が分る。これは上㖽結節や Tuberculum spinosum, Spina pterygoidea anterior, 翼窝の横径の大小 (enge, weite Fossa) を考学てみれば当然の事である. この事より私性側面投影で简の長径と同一線上でしか子 刺入㭙もつと为障害物の少ない下方外側より行う Ostwalt 法が刺入針尖を翼简内に 到達させるのに最適であ ると判断したのである.しかし唒頭蓋骨による統計学的 見地からする翼窩内刺入率は 成程 Ostwalt 法が儤秀だ がこれを臨床的に追試してみるとこの方法で翼窝内に刺 入することは仲々容易でなく Ostwalt法の交献を読んで も詳細な具体的刺入方法は記されてない仮令翼窝内に刺

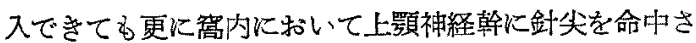
せることは（当然の経果として患者は神経衝撃を訴える 等である）これ又仲々難事であることが分つたので， 第 1 段階として翼䆟に確実に刺入し得る方法を案出し次 に第 1 表により分る様に Ostwalt 法は 翼謇刺入率は良 好だが第 2 表の如く正円管到達率が满足すべきるのでな
第 2 表 (その1)

Matas-Braun 法比よる正阴管到達称（野村）

\begin{tabular}{|c|c|c|c|}
\hline & 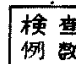 & 刻 & 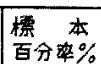 \\
\hline$\hat{\delta}$ & $\begin{array}{l}63 \\
63\end{array}$ & $\begin{array}{l}50 \\
53\end{array}$ & \begin{tabular}{|l|}
79.37 \\
84.13
\end{tabular} \\
\hline 古友 & $1 / 3$ & 12 & $\begin{array}{l}93.31 \\
84.62\end{array}$ \\
\hline
\end{tabular}

Sicher 法による正円管到達率（野村）

\begin{tabular}{|c|c|c|c|c|}
\hline & 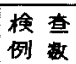 & \begin{tabular}{|ll} 
制 & $\lambda$ \\
例
\end{tabular} & 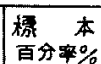 \\
\hline$\S$ & $\mid$\begin{tabular}{|l|} 
左 \\
石
\end{tabular} & $\begin{array}{l}63 \\
62\end{array}$ & $\begin{array}{l}48 \\
49\end{array}$ & \begin{tabular}{|l|}
76.2 \\
77.4 \\
\end{tabular} \\
\hline+ & \begin{tabular}{|l|} 
右 \\
右 \\
\end{tabular} & $\begin{array}{l}13 \\
13\end{array}$ & 9 & $\begin{array}{l}69.2 \\
84.6\end{array}$ \\
\hline
\end{tabular}

Blumental 法による正朾管到達率（野村） 正円管入口部内及び直前に莱するるの

古左 (61) (27) $44.3 \%$, 右 (63) (23) $38.8 \%$

平左 (13) (6) $46.2 \%$, 右 (13) (5) $38.5 \%$

煩骨弓下縁より行う Offerhaus 法による正円管到達

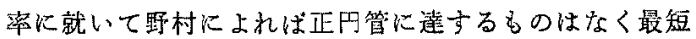
注正円管前方 $2.0 \mathrm{~mm}$ であった。

第 2 表 (乞の2)

Ostwalt 法に上る正円管到逵率（内藤）

Ostwalt は刺入点を第了大日潘後方と稍的然とした 表現をしているので私は次のような方法で到達率を求め

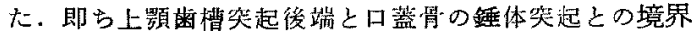
部から Fossa 入口部後縁を結びその延長楾が正円管入 口部を通過するや否やを椧べた。

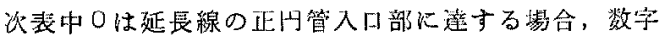
は延長線が正円管入口部上り唯机て通過する場合の正円

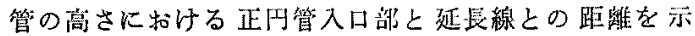
与(単位 $\mathrm{mm}$ ).

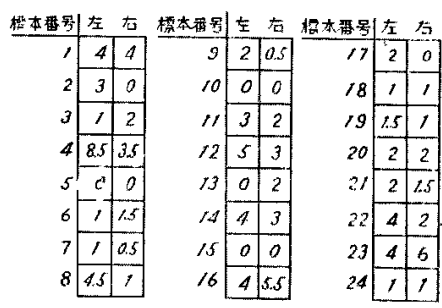

第 2 表（その3)

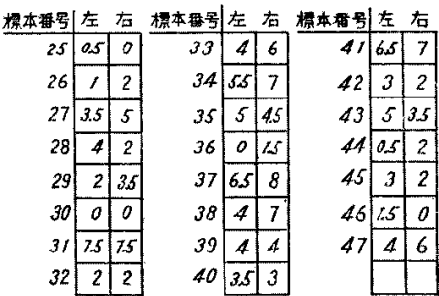




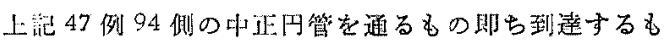

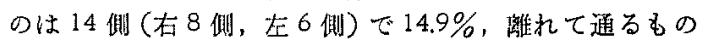

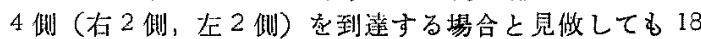

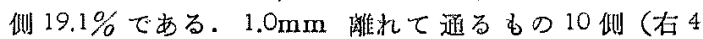
側，在 6 側）を加之た場合には $29.7 \%$ となる。

い期的第 2 段階としての正円孔部刺入方法を研究する ことにし先つ Ostwalt 法による Fossa 刺入に際し側面 及び正面功ら見てできるだす判然とした刺入目標を与え るための研究を行つた。

III Ostwalt 法による翼瓷刺入のだに頭蓋骨'側面 より兄た刺入目標（第 4 図及び第 3表）

\section{第 4 図}
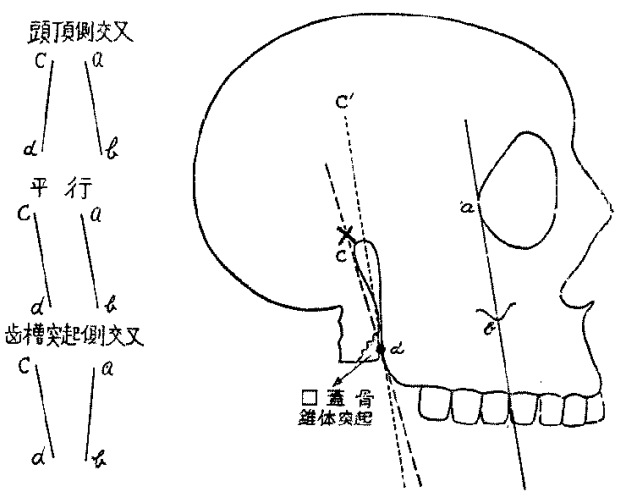

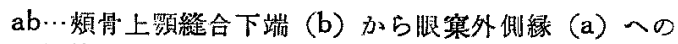
切線

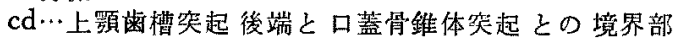

(d) 加 5 Fossa 入口部後縁 (c) を通つて Foramen rotundum 乃至その前方に遠する袙

c'd ‥上顎齿槽笑起後端と口蓋骨錐体突起との境界部 を通り $\mathrm{ab}$ に司行に引いた線

$\times \cdots$ Foramen rotundum の位稙

\section{第 3 表 (その1)}

$\mathrm{ab}$ ，及び cd の延援線が槽突起側で交叉する場合を 記号 $V$, 頭頂側で交刃する場合を記号 $\wedge, a b$,及び cd が平行線を示す場合を記号 11 で示す.

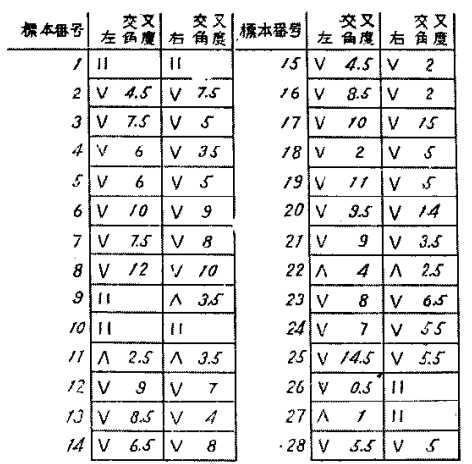

第 3 表 (その 2)

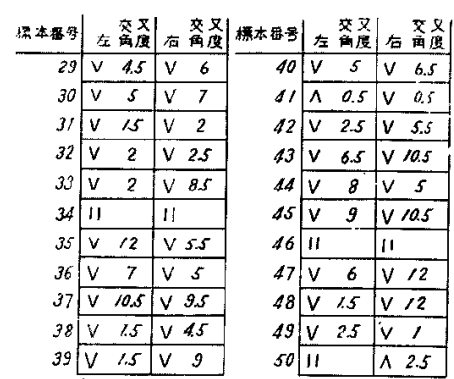

（1）唒頭蓋骨 50 例 100 側の中第 4 図の ab 線と cd 線とが全く平行なるもの12 側 (左6 侧, 右6 側).

(口) ab と cd が平行でなくとの延長線が歯槽突起 側で效文するもの80 側 (左 40 側, 右 40 側). その中效 有 10 度以上のもの (10度を含主) 14 側, その中最大交 㕛角度を示せるものは 15 度 (1 側) であつた。

(八) $\mathrm{ab} ，$ cd が平行でなくその延長線が頭項側 で交正るすの8 側 (左 4 側，右 4 側) であつた. 以上 の 50 例 100 側に就いて ab 線亡平行に点線 c'd の方向 に1/1 の刺入針を朋いて翼窝への刺入いかんを試みた結 果次の事が分つた。（1）群に属する 12 側では全例刺入 可能.（口）群に属する 80 側の中第 3 表䏇本番号 4 の左 右翼窝は夫々横径 $2.0 \mathrm{~mm}$ という enge Fossa のため 蝴入や今困難，文標本番号 8 及び 44 の左側では第 5 図 (a) の如く上顎結節後上半部が極端に後方に膨隆してい るため針尖ぶこれに突き当つて刺入不可能.

第 5 図

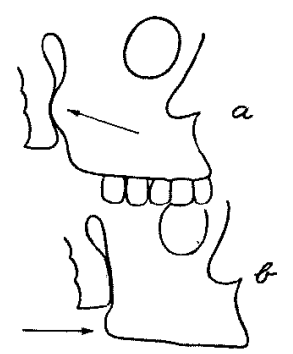

矢標本番号 41 , 右側例は第 5 図 (b) の如く歯慒突起 後端の異常突出のため刺入不可能.

（八）群に属する8 側けいずれる刺入不可能なるる交 叉触が小さいので（4度以下）剌入針尖を極くわずか 前万に移動することにより刺入可能となる。

即ら酔骨標本 50 例 100 側中 97 側に和いて煩骨上顎縫

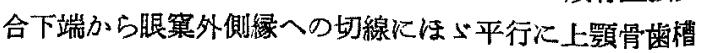


突起後端と口蓋骨錐体桇起との境界部より刺入を行えば

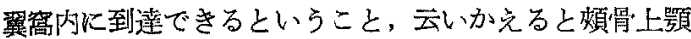

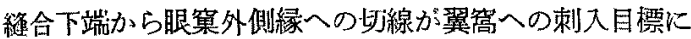
なるといらことが分った。

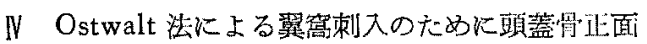
より見た正中面に対する刺入角度（第６図攻び 第 4 表， 5 表)

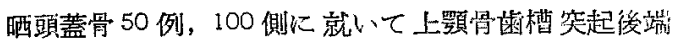
と口蓋骨錐体突起との境界部と正円孔の中心顶至その前

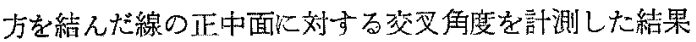

第 6 図

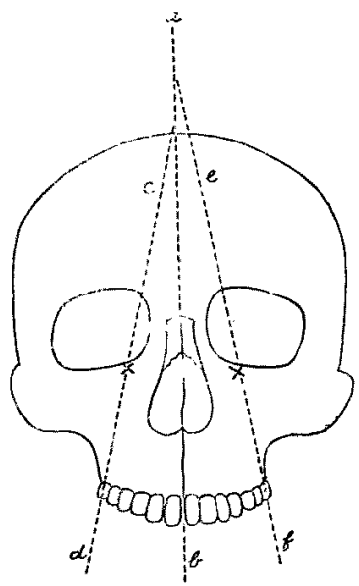

$\mathrm{ab} \cdots$ 正中線（面）

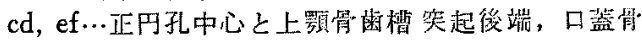
鏙体笑起境界部を結んだ線

×…正円孔の高さの位置

第 4 表 (その 1)

第6图の正中面 $\mathrm{ab}$ に対し cd 及び ef はいず杞も頭 頂部方向で交攴する。その艾齐角度は下表の如し

\begin{tabular}{|c|c|c|c|c|c|}
\hline 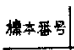 & 空 & 苔 & 魥态舆号 & 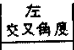 & 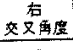 \\
\hline 7 & $\prime \prime$ & 11 & 17 & 7 & $s$ \\
\hline 2 & 9 & 5 & 18 & 8 & 5 \\
\hline 3 & 11.5 & 13.5 & 19 & 9 & 7 \\
\hline 4 & 娜足不能 & 5.5 & 20 & 4.5 & 7.5 \\
\hline$s$ & 7.5 & 8 & 21 & 15.5 & 10 \\
\hline 6 & 7.5 & 6.5 & 22 & 6 & 6.5 \\
\hline 7 & 5.5 & 5 & 23 & 12.5 & 12,5 \\
\hline 8 & 11 & 8.5 & 24 & 3 & 8.5 \\
\hline 9 & 8 & 8 & 25. & 10 & 85 \\
\hline 10 & 8 & 8.5 & 26 & 9 & 9 \\
\hline$n$ & 71.5 & 10.5 & 27 & 10.5 & 10 \\
\hline 12 & 12.5 & 12 & 28 & 7 & 9 \\
\hline 13 & 8 & 6.5 & 29 & 8. & 1.5 \\
\hline 14 & 6 & 4.5 & 30 & 15 & 7 \\
\hline 15 & 9 & 7.5 & 31 & 6.5 & 3 \\
\hline 16 & 11 & 11.5 & 32[ & 9 & 8 \\
\hline
\end{tabular}

第 4 表（その 2)

\begin{tabular}{|c|c|c|c|c|c|}
\hline 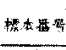 & 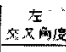 & 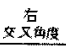 & 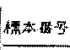 & 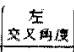 & 壱 \\
\hline 33 & 8 & 7.5 & 42 & 9 & 9 \\
\hline 34 & 12,5 & 10 & 43 & 14 & 8 \\
\hline 35 & 1.5 & 35 & 44 & 8 & 8.5 \\
\hline 36 & 13 & 13 & 45 & 15.5 & 7 \\
\hline 37 & 8 & 7.5 & 26 & 185 & 11.5 \\
\hline 38 & 5 & 25 & 47 & 9 & $g$ \\
\hline 39 & 15 & 4.5 & 48 & 17 & 11.5 \\
\hline 40 & 8 & 8 & 49 & 7 & 9 \\
\hline 41 & 9 & 6 & 50 & 6.5 & 5 \\
\hline
\end{tabular}

桧查例数左右合計 100 側の中 交文角度 $4.5 \sim 13$ 度のもの 88側, 1.5 4.0度のもの 5 侧, 13.5 17 度の8 9 6 侧, 测定不能 1 側. 正中面儿効する交叉角度左右各 50 側の中 樶小なる向の左右共 1.5 度各 1 㑡 最大なるもの左 17 度 1 側, 右 13.5 度 1 側。

第 5 表 交叉角度々左右合諳倒数との関係 (99 側)

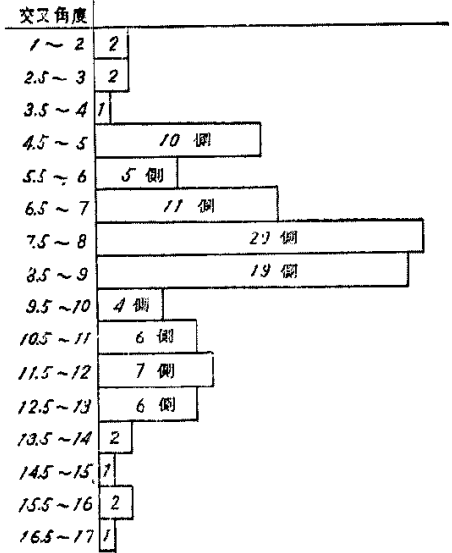

は第4 表の如くなつた，しかして第5表により交列角度 4.5 13 度のものは 88 側 88\%に達し頭蓋骨を正面より 見て Ostwalt 法で翼简への刺入に際し有力な手䀣りと なる。

V III (側画) ZびN（正面）の刺入目標, 刺入角 度を用いて Ostwalt 法による翼简刺入（臨床 的試攻)

【1項及び V 項で述べた如く煩骨上頻縫合下端から眠巢

\section{第 7 図}

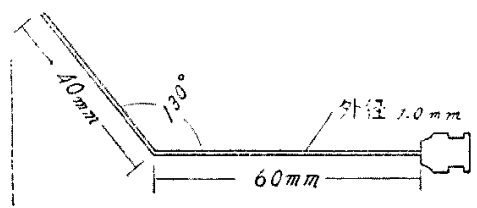




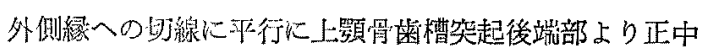

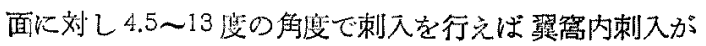

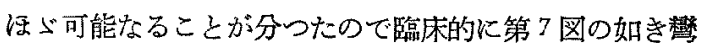
㭗針を用いて誠み圠。

\section{その結果は}

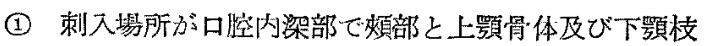
に挾昰机て和り非常以狭い。

(2) 晒骨標本では下颚骨疍取り除いて計測したつめ臨床

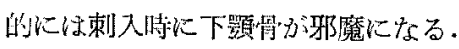

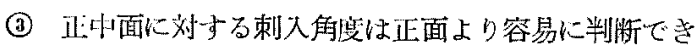
るが，同時に側面上りの目整として煩留上顎縫合下端か

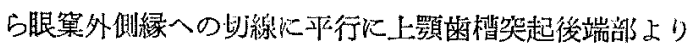
刺入せねね゙゙ならぬのに口腔内深部に位置する刺入針は煩

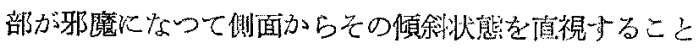
ができず忽角不正確になり勝らであり，又刺入時正中面 Z攵び側面の 2方向に注意を配ることは大変煩わしく engc Fossa の場合には濯窝内刺入に失敗することが多い。

(4) 普通の外保 $1 / 1 \mathrm{~mm}$, 長さ $10 \mathrm{~cm}$ の注射針を唯西げ て試作したもので腰が弱くて思ら方向へ刺入すること

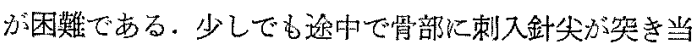
ると注射針が堯つて以挠方向を变えることが難かしくな る.

以上のような理由で麻醉成樍は良好ではなかった。 そ してこの方法で刺入時最も困惩したことは果して確実に 針尖が翼㬔内で上顎神経に值達乃至は至近距離に達して いる否やはつきり泆められ妨ことで彷来の方法のよう

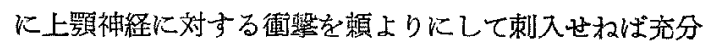
な秼醉効果を得られ婸合が多いことである。翼窝内で 刺入針尖を神释幹に直澾させることは熟練者によつて刺 入が行われた際でも10\%内外といら低率で一般には困 難視されている。このことは Ostwalt 法が技術的問題 あさることながら從来括てつ省みられなかつた大きな原

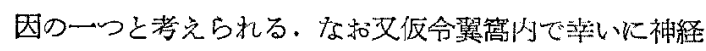
幹乃至はその附近に薬液を注入し得たとしても weite Fossa の例の中には正円孔部を遠く離れた期所に刺入針 尖が達し N. infraorbitalis への注射となる場合も起り 得る.その結果俚麻酔奻果が低下してしまうことは必定 である。このことは上述の』項及びN 項の刺入目標，刺 入角度により Ostwalt 法で徆頭蓋骨 50 例 100 側により 害験的に刺入を行つた際の侧面投影火打ける刺入針之

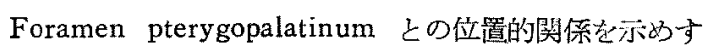
第6表によつて明らかである。即ちこの第6表の中で左 側の標本番号 4, 7, 8, 13，17，20，25，30，35，36，37,
第 6 表 (その1)

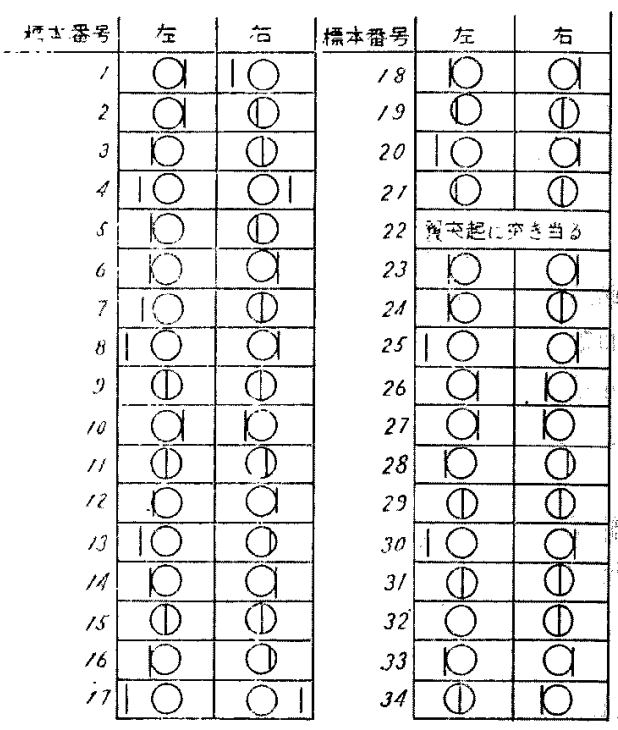

第 6 表（その2）

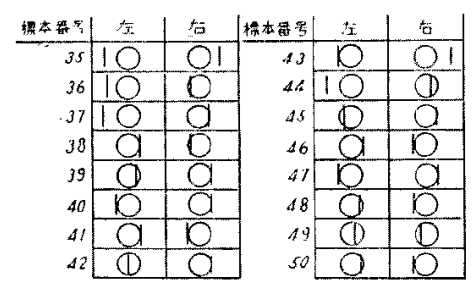

O...Foramen Pterygopalatinum

1 …刺入針の位監

44, 右側の標本番号 4，17，35，43はいずれも麻酔効果が 不充分になる可能性のある例である.

VI 刺入針尖を Fossa 内で上顎神経に直達乃至は 至近距離へ到達させるために各症例毎の刺入架 度の決定の矵究並びに臨床的試み

翼简内に执いて上顎神経へ針尖を到達させるための刺 入距離に就いて解剖学的に唒骨を检討している中に第1

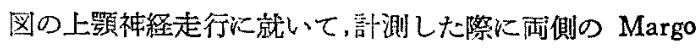
orbitalis inferior の最低点之一側の頖骨水平突起, 同上 行突起とのなす隅角部とを結えで側頭部に沿ら前後の延

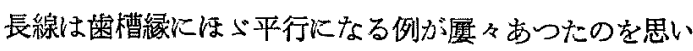
出した。この事から更に Margo orbitalis inferior の最 但点より潾槽縁迄の距離な Foramen rotundumより蒾 槽縁を後方に延長した線沦の距離にほ心゙等しいのでな いかと考宎早速計测してみたところ次のような数值を得 た（第 7 表〜第 10 表，及び第 8 图）. 
第 8 図
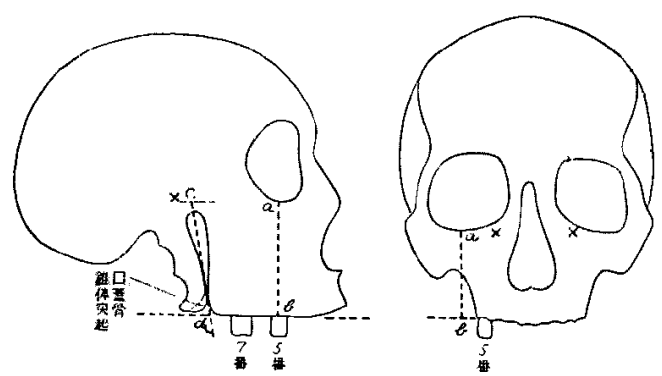

$\times$...Foramen rotundum

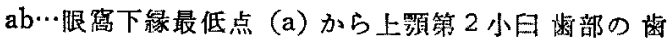

㮐䋑の高さ (b) 迄の距崔

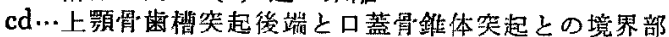

を通つて正円孔下緑乃至气の前方で下緑の高さ似 相当する点 (c) から上類 $5,6,7$ 番（第 2 小目海，

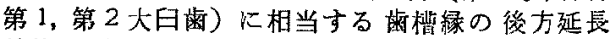
楾迄の距離

第 7 表 （その1）（䍹位 $\mathrm{mm}$ )

\begin{tabular}{|c|c|c|c|c|c|}
\hline \multirow[b]{2}{*}{ 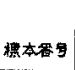 } & \multicolumn{2}{|c|}{ 左 } & \multirow[b]{2}{*}{ 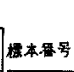 } & \multicolumn{2}{|c|}{ 右 } \\
\hline & 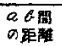 & 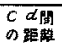 & & 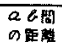 & 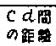 \\
\hline 1 & 43 & 15 & , & 44 & 41 \\
\hline 2 & 48 & 52 & 2 & 43 & 44 \\
\hline 3 & 34 & 42 & 3 & 36 & 38 \\
\hline 4 & 33 & 34 & 4 & 36 & 40 \\
\hline 5 & 35 & 38 & $s$ & 36 & 37 \\
\hline 6 & 36 & 38 & 6 & 37 & 37 \\
\hline 7 & 37 & 38 & 7 & 37 & 38 \\
\hline 8 & 47 & 47 & 8 & 46 & 44 \\
\hline 9 & 43 & 43 & 9 & 40 & 46 \\
\hline 10 & 34 & $3 ?$ & 10 & 33 & 34 \\
\hline$\| \prime$ & 24 & 40 & $\prime$ & 44.5 & 40 \\
\hline 12 & 34 & 37 & 12 & 35 & 37 \\
\hline 3 & 15 & 39 & 13 & 47 & 42 \\
\hline 14 & 38 & 40 & 14 & 38 & 39 \\
\hline 15 & 45 & 48 & 15 & 42.5 & 43 \\
\hline 16 & 39 & A1.5 & 16 & 39 & $\Delta \prime$ \\
\hline 17 & 44 & 41 & 17 & 44 & 39 \\
\hline
\end{tabular}

第 7 表（その2） (単位 $\mathrm{mm}$ )

\begin{tabular}{|c|c|c|c|c|c|}
\hline \multirow[b]{2}{*}{ 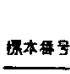 } & \multicolumn{2}{|c|}{ 左 } & \multirow[b]{2}{*}{ 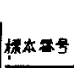 } & \multicolumn{2}{|c|}{ 石 } \\
\hline & 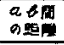 & $\begin{array}{l}c d A_{A} \\
\text { o }\end{array}$ & & $\begin{array}{l}\text { Q \& } \\
\text { or }\end{array}$ & 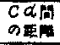 \\
\hline 18 & 42 & 10 & 18 & 42 & 39 \\
\hline 19 & 48 & 47 & 19 & 48 & 45 \\
\hline 20 & $4 A$ & 45 & 20 & 45 & 42 \\
\hline 21 & 32 & 34 & 21 & 30 & 34 \\
\hline 22 & 42 & $4 a$ & 22 & 43 & 37 \\
\hline 23 & 42 & 42 & 23 & 44 & 12 \\
\hline 24 & 41 & 42 & 24 & 40 & 39 \\
\hline 25 & 42 & 40 & 25 & 42 & 37 \\
\hline 26 & 40 & 38 & 26 & 39 & 37 \\
\hline 27 & 44 & 44 & 27 & 44 & 41 \\
\hline 28 & 36 & 39 & 28 & 35 & 36 \\
\hline 29 & 4.4 & 40 & 29 & 45 & 40 \\
\hline 30 & 35 & 35 & 30 & 35 & 34 \\
\hline $3 \prime$ & 38 & 36 & $3 \prime$ & 40 & 37 \\
\hline 32 & 36 & 34 & 32 & 37 & 36 \\
\hline 33 & 42 & 44 & 33 & 14 & 41 \\
\hline 34 & 41 & 40 & 34[ & 40 & 39 \\
\hline
\end{tabular}

第 7 表 (その3) (単位 $\mathrm{mm}$ )

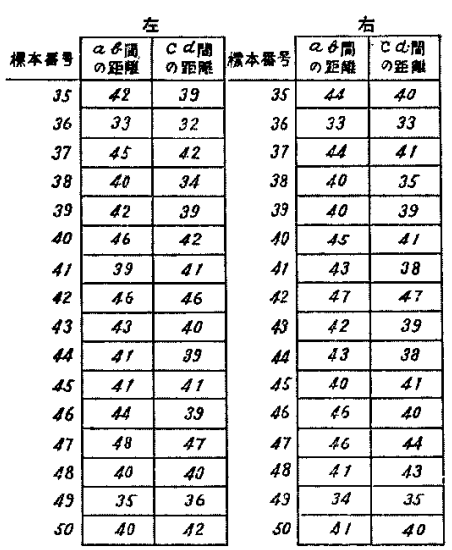

第 8 表

\begin{tabular}{|c|c|c|c|c|c|}
\hline \multirow{2}{*}{\multicolumn{2}{|c|}{ 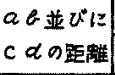 }} & \multicolumn{2}{|c|}{ 在 } & \multicolumn{2}{|c|}{ 右 } \\
\hline & & $a b$ (側) & $c d$ (侧) & \multirow{2}{*}{$\frac{a b(\text { 倒) }}{1}$} & $c d($ (例) \\
\hline $30 \mathrm{~m}$ & & & & & \\
\hline 32 & $\pi$ & 7 & 2 & & \\
\hline 33 & * & 2 & & 2 & 1 \\
\hline 34 & + & 3 & 4 & 7 & 3 \\
\hline 35 & . & 4 & 1 & 3 & 2 \\
\hline 36 & . & 2 & 2 & 3 & 2 \\
\hline 37 & * & 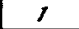 & 1 & 3 & 7 \\
\hline 38 & * & 2 & 4 & 7 & 4 \\
\hline 39 & + & 2 & 6 & 2 & 7 \\
\hline 40 & . & 4 & 9 & 7 & 6 \\
\hline 41 & : & 4 & 3 & 2 & 7 \\
\hline 415 & 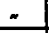 & & 1 & & \\
\hline 42 & + & 7 & 6 & 3 & 3 \\
\hline 42.5 & $\dot{.}$ & & & 1 & \\
\hline 43 & . & 3 & 1 & 4 & 2 \\
\hline 44 &. & 6 & 2 & 7 & 3 \\
\hline 44.5 & 4 & & & 7 & \\
\hline 45 & 4 & 3 & 2 & 3 & 1 \\
\hline 46 & 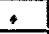 & 2 & 1 & 3 & 1 \\
\hline 47 & . & $I$ & 3 & 2 & 1 \\
\hline 48 & + & 3 & 1 & $t$ & \\
\hline \multirow{2}{*}{52} & . & & 1 & & \\
\hline & & 50 & 50 & 50 & 50 \\
\hline
\end{tabular}

ab 間區離の最少なるもの

$$
\text { 左 } 32 \mathrm{~mm} 1 \text { 断 }
$$

cd 間距離の最小なるるの

t $32 \mathrm{~mm} 2$ 侧

$\mathrm{ab}$ 間弫離の最大なるもの

左 $48 \mathrm{~mm} 3$ 側右 $48 \mathrm{~mm} 1$ 側

cd 䦓距離の最大なるもの

$$
\text { 左 } 52 \mathrm{~mm} 1 \text { 侧 }
$$

$\mathrm{ab}$ 間距雄 50 側の平均值は

$$
\text { 左 } 40.64 \mathrm{~mm}
$$

$\mathrm{cd}$ 間距離 50 侧口平均檤怡
左 $40.29 \mathrm{~mm}$
右 $39.40 \mathrm{~mm}$ 
第 9 表 符 7 表を分類すると $\mathrm{ab}$ 闑距離と $\mathrm{cd}$ 間距 離の等しい当の 11 側

又 $\mathrm{ab}$ 間距離と $\mathrm{cd}$ 閫距離に差のるるのは下裴の 如 ᄂ

\begin{tabular}{|c|c|c|c|c|c|}
\hline \multirow{2}{*}{ 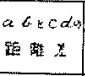 } & \multicolumn{2}{|c|}{$t$} & \multicolumn{2}{|c|}{ 石 } & \\
\hline & $\begin{array}{l}a \operatorname{tancd}^{2} \\
d \| t\end{array}$ & {$\left[\begin{array}{l}\csc s \\
d x\end{array}\right.$} & $\begin{array}{c}a \bar{z} \operatorname{sicd} \\
x \leqslant 1\end{array}$ & $\begin{array}{c}\text { cathat } \\
\text { dit }\end{array}$ & \\
\hline $0.5 \times 10 \mathrm{~mm}$ & $s$ 側 & 5 㑬 & 6 副 & 9 缴 & 25 (냉 \\
\hline $2.0 \mathrm{~mm}$ & 7 伯! & 7 湖 & $\Delta$ 解 & d 側 & 22 伊 \\
\hline $2.5-3.0 \mathrm{~mm}$ & 5 细 & 5 㑬 & $g$ 侧 & 0 & 19 眮 \\
\hline $40 \mathrm{~mm}$ & 3 知 & $\gamma$ 䐓 & 2 侧 & 2 㑡 & 8 側 \\
\hline $45 \sim 50$ man & 1 性l & 0 & 8 俦 & 0 & 9 碽 \\
\hline $60 \mathrm{~min}$ & 2 测 & 0 & 2 咧 & 1 唃 & 5 恻 \\
\hline $7.0 \mathrm{nmm}$ & 0 & $0^{\circ}$ & 0 & 0 & \\
\hline $8.0 \mathrm{~mm}$ & 0 & / 封 & 0 & 0 & 1 湖 \\
\hline & 23 側 & 19 倨 & $3 /$ 例 & 16 措 & 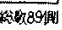 \\
\hline
\end{tabular}

\section{第 10 表}

O..... Foramen rotundum

$\times \cdots \cdot \cdot \mathrm{a}$ 点
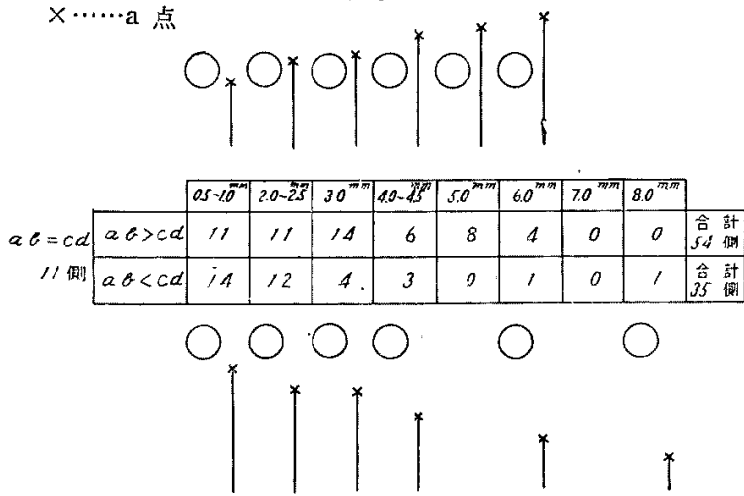

榆查総数左右合計 100 侧飞就いてd 点を基点として cd 上に abを重初た際の a 点の位㯰の高さと Foramen rotundum の位䁂の高さとの関係（第 8 図参照）

即々检植総数左右合計 100 側の中で

(1) 第8图でab が cd より大なるものは54 僛（左23 側，右 31 側) で事半数を占めている.この中 $\mathrm{ab} と \mathrm{~cd}$ の距淮差が $0.5 \sim 3.0 \mathrm{~mm}$ 迄のものが 36 僛(左 17 側, 右 19 側) で測定せる $\mathrm{c}$ 点は Foramen rotundum の下 縁の高さに相当与る故，この36 側及び ab 間距離と cd

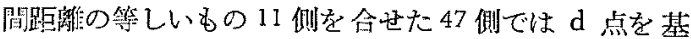
点として $a b$ を $\mathrm{cd}$ に重社ると $\mathrm{a}$ 点はほぶ正円孔前方で その下㜊より上綄泛の閒の高さに位犆することになる。

(2) $\mathrm{ab} \mathrm{が} \mathrm{cd}$ 上り大なるものでての差が $4.0 \mathrm{~mm}$ のも の 5 侧 (庄 3 侧, 右 2 侧)，4.5 5.0 mm のbの9 側 (左 1 侧, 右 8 侧)，6.0 mm のbの4 侧 (左 2 側, 右 2 侧) を合ぜた 18 侧では d 点を基点として $\mathrm{ab}$ を $\mathrm{cd}$ 亿電小 ると a 点の位琶は正円孔上縁の高さを通り越して 2,0〜 $3.0 \mathrm{~mm}$ 上方に位監することになる。

(3) $\mathrm{cd}$ が $\mathrm{ab}$ より大なるるの」中 cd と ab の距離差
が $0.5 \sim 3.0 \mathrm{~mm}$ 迄の6030 側 (左 17 側, 右 13 側) で

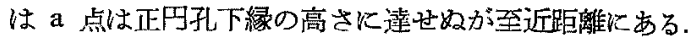
(4) $\mathrm{cd}$ が $\mathrm{ab}$ より大なるものでその差が $4.0 \mathrm{~mm}$ のる の 3 側 (左 1 側, 右 2 側), $6.0 \mathrm{~mm}$ のもの 1 側（左0側 右 I 側), $8.0 \mathrm{~mm} の も の 1$ 側 (左 1 側, 右 0 側) の合㖕 5 側では a 点は正円孔下縁の高さより稍々下方に離れる が检査総数の $5 \%$ に過ぎない。

以上により ab 即ち Margo orbitalis inferior の最低 点より菌槽縁迄の距稚は cd 即占 Foramen rotundum 下縁の高さ」り歯榑縁後方延長線迄の距離と汪心等しい ことが分つたのでこれを臨床的に利用寸ることにより刺 入針尖を上顎神経に值達乃至は至近距離に至らしめ得る

筈であると考えた・な特上述の(1)〜(4)の中で臨床的 に問題になるのは(2)及び(4)の場合であるが前者で は Fossa 内に刺入せられた針尖を無謀に上内方に 進めることなく常に慎重なる刺入を心腦心れれば視神 経の損傷は全く避けられるし（第 11 表参照）後述 する方法で翼蓇内に刺入せられた針尖を引き涜いて Foramen rotundum ح间わせる際の頭葢内愦刺入 の危険子第 4 図に示した $a b$ 線に平行に c'd に沿 つて実験的に刺入針を翼窝に刺入した場合の正円孔 部の高さに和子る刺入針尖の位置から正円孔入口部 迄の距離（第 12 表）を歁釣すれば䂆方することがで きる。

爻後者の(4)場合では翼窟内に刺入せられた針发 は上顎神経の下方 4.0 〜 $8.0 \mathrm{~mm}$ でや〉遠く離机るが

第 10 表の如く検查絰数 100 側中 5 側に過ぎず後述 する法で引き緢き針头展 Foramen rotundum 万间へ 向わせることにより Planum Pterygoideum に突き当

第 11 表 Foramen rotundum $と$ Foramen opticum 間の距離（巣位 $\mathrm{mm}$ ) (検查例数 50 例 100 僛)

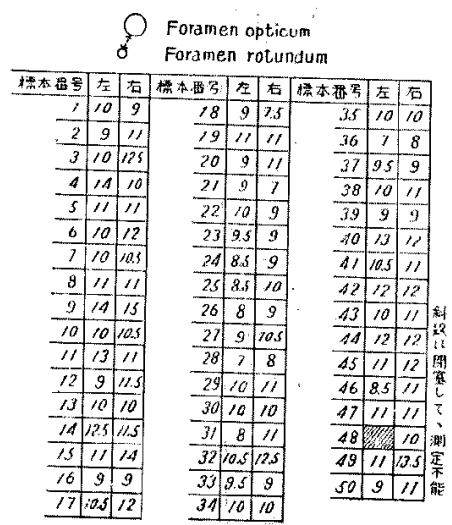


第 12 表 第 8 图の $\mathrm{c}$ 点（正円孔部の高さに和ける刺 入针尖の位置)より正円孔入口部迄の距離(粆位 $\mathrm{mm}$ )

\begin{tabular}{|c|c|c|c|c|c|c|c|c|}
\hline 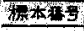 & 左 & & 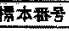 & te & F & 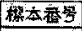 & & 右 \\
\hline$y$ & 4 & & 18 & 7 & 5 & 35 & 70 & 8 \\
\hline 2 & 5 & 4 & 79 & 35 & 3 & 36 & 9 & 9 \\
\hline 3 & 6 & 6 & 20 & 7 & 9 & 37 & 10 & 85 \\
\hline 4 & 10 & 5 & $2 t$ & 15 & 4 & 38 & 0 & 2 \\
\hline 3 & 2 & 2 & 22 & & & 33 & 7 & $\frac{2}{12}$ \\
\hline 6 & 7 & 15 & 23 & 6 & 5.5 & 20 & 6 & 10 \\
\hline 7 & A & & 24 & 18 & 6 & 41 & $A$ & 4 \\
\hline 8 & 10 & 5 & 25 & 10 & 9 & $\overline{42}$ & 5 & 6 \\
\hline 9 & 2 & & 26 & 5 & 7 & 23 & 8 & 72 \\
\hline 7 & $t$ & $t$ & 27 & 71 & 0 & 44 & 6 & 4 \\
\hline 11 & 3) & 㱠 & 28 & 3 & 5 & $\overline{45}$ & 8 & 9 \\
\hline 72 & 6 & 5 & 29 & 5 & 7 & 46 & 0.5 & 2 \\
\hline 13 & 5 & 3 & 30 & 76 & 5 & 47 & 6 & 8 \\
\hline 14 & 25 & 25 & 31 & 4 & 4 & 48 & 2 & 2 \\
\hline 15 & 31 & 4 & 32 & 0 & 0 & 49 & 6 & 6 \\
\hline 76 & 3 & & 33 & 8.5 & 1715 & 50 & 2 & \\
\hline 77 & \begin{tabular}{|l|}
7 \\
\end{tabular} & & 34 & 2 & 2 & & & \\
\hline
\end{tabular}

（噇）斜螕は刺入針失が翼突起に当りFossa K入 $5 \propto$ 侧の例

たるのでそこから Foramen rotundum を探机ばよい。

ところで手術時に ab 即ら Margo orbitalis inferior

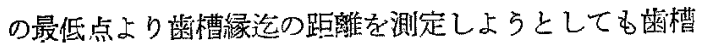

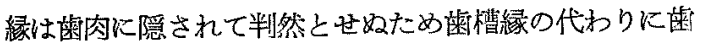
牙晈合面方湘定目標にならないるのかどうかを㞍的的に 解剖学教室にある完全に道牙の残存せる例により計測し

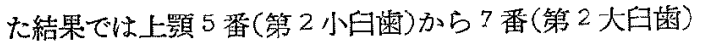

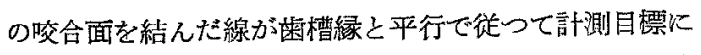
適することが分り上述の方法を臨床的に試みた。即ら麻

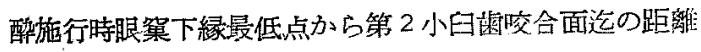

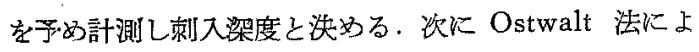
り上顎齿槽突起後端部より䍌曲部の長さ $5.0 \mathrm{~cm}$ (この長 さは第 8 表の数值より適当と認めた）の注射針を刺入す る・な扢この目的のために刺入針の腰强化せるるのを 試作した（第9図）。

第 9 図

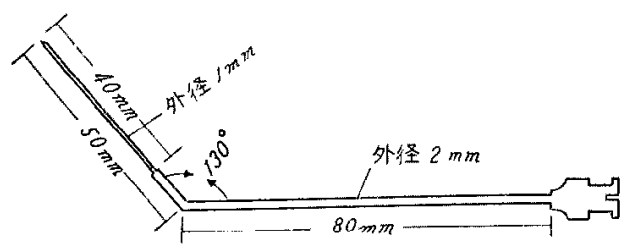

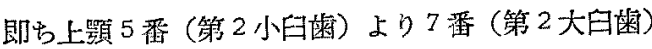
の盿合面を結えた線を基潐として棶槽实起後端部より 正中面に対し 4.5 13 度の鋭角で眼笨外側縁上煩骨上顎 縫合下端を結ふ線に平行になるよらに刺入を行い眼窠下

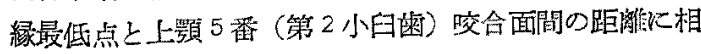

当する刺入梁度に達すれば針头は Fossa 内で上顎神経 に到迲乃至はその至近距猚汇ある筈であるが前述せる

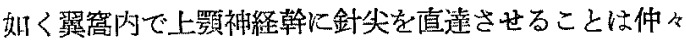
難しいので予定濯度附近で上，下，左，右，前，啳に少 しづ〉針尖を移動させて神経㣫踒を訴える位固を探すの だが若し神経幹に当らなくてもその附近に菂液を撒布で きる有利さがある。この方法を臨床的に試みて得た麻酥

第 13 表 麻 酔 効 果

$\begin{array}{cccc}\text { 效果 } & \text { 症 例 } & \text { 該当例数 } & \text { 症例百分率 } \\ \text { (H4) } & 40 \text { 例 } & 6 \text { 例 } & 15.00 \% \\ (H) & 40 \text { 例 } & 13 \text { 例 } & 32.50 \% \\ (+) & 40 \text { 例 } & 21 \text { 例 } & 52.50 \% \\ (-) & 40 \text { 例 } & 0 & 0 \%\end{array}$

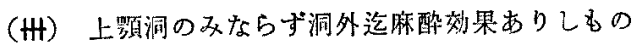

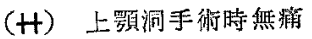

(十)上颚洞手術時一部に疼痛ありしもの

(一) 砳酷果なきもの

效果は第 13 表の如くであるが次のような欠点が判明し た・即ら

(1) 刺入針を最初から Ostwalt 洗の方向に 即ち上顎米 槽㚙起後端部より翼简方向に刺入しょうとすると $5.0 \mathrm{~cm}$

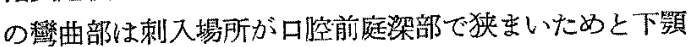
が邪魔になつて仲ヶ思ら力间へ刺入できない場合が多 w.

(2) 目䅺方间人刺入できた場合でも更に注射針安淮めて

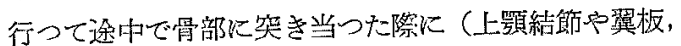

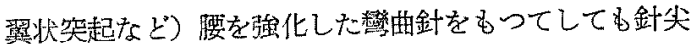
の方向を变光ようとすると口腔梁部のため仲々思らよう にならず翼简への刺入にはな手古揊ることがある。殊 に針尖が翼䈑の後方の翼板纴至翼状突起八向つた際にこ

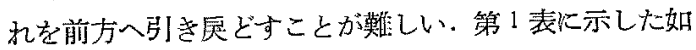

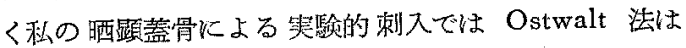

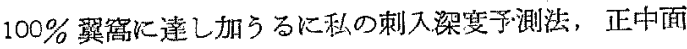
に対する刺入角度，側酸上り見た刺入目標により刺入針 尖が翼简内において上顎神経の至近距離に造している等

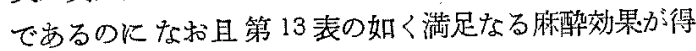
られないといら解部学的検詰結果と陪床的効果との間の

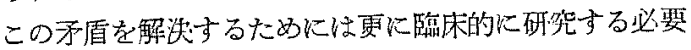
性を痛感した。即る

(1) Ostwalt 法の刺入方向に最初からは徒的ず（途中か 5 Ostwalt 法の方向に直す）に刺入点及び刺入方法を

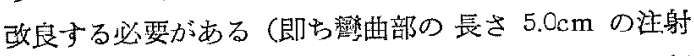

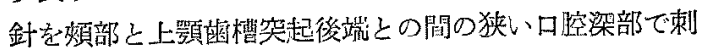


入し易い方法を見出す).

(2) Ostwalt 法そのま〉を追試する限りに执いては第 2 表の如く正円管到達率は満足すべきものではなく私の刺 入梁度の予測法や刺入角度の 助けをかりても第 13 表の 如く満足な麻酥効果の得られぬ場合がかなりある. それ 故每常麻醉効果を充分にするためにはどうしても正円孔 部へ刺入針尖を到達させる必要がある事が分つた。

な抗こつで翼窝刺入といら問題に関する限りにおいて 前述した项項，N項，V項を併用した場合の Ostwalt 法での特徵を述べると刺入針尖が 翼筥内に入ら限り は刺入距離（第8図 cd）が予測距離（第8図 ab）に 達し得ないと考えてよいことで（勿論例外はあるが稀で ある). 晒顕蓋骨 50 例，100 側で実験したところ針尖が 翼窝外にあつて刺入距離之予測距離の等しかつたもの 1 例 (2 側), 刺入距離が令測距離より大であつたもの1 例 (2 側)……これ等の揚合刺入針尖は蝶形骨大翼の Facies infratemporalis に突き当つた…....除き残り 48 例，96 側に打いては針尖が窩外にある限り刺入距離は予測距離 に達せず上頸結節や翼突起，翼板に当つた. 上記の 2 例 4 側も正中面にほよ゙平行乃至は上外方に刺入針を進めた 場合のことで私の方法の刺入角度を厳守する限りは問題 にならない。

次に刺入角度を（第 4 表，5表）余り大きくして 翼窝 内に刺入した場合には針尖は時には蝶形骨体へつき当た クあるいは Foramen Pterygopalatinum より鼻挖内へ 抜けることも起り得る．前者では刺入距離（第8 8 四 $\mathrm{cd}$ )

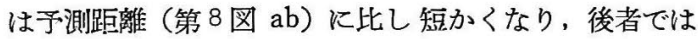
逆に長くなる.いずれの場合にも正円孔部を溒く離れて しまうが前揭の刺入角度を守ることによりこの失敗も防 げる. 即ち Foramen rotundum の位置は翼窩内で後上 方外側部に寄つている故予測距離を刺入し終つた時の刺 入角度は必ず大き過ぎてはならない。

即ち Fossa への刺入という点では前述の $\mathbb{I}, \mathbb{N}$, VI項 によつて初心者にも容易に施行し得るものと信ずる.

VII 私のOstwalt 改良法により翼窩に刺入せられた 針尖を引き続き正円孔部へ達せしめる方法.

毎常充分なる麻醉効果を得るためには是非共正円孔部 奌刺入針尖を到達させることの必要性は前述したが第 1 表に示した各氏の翼荷刺入率を夫タ第 2 表の正円管到達 率と比較して見ると全く逆の成績を示している事が分 る. 即ち翼窩刺入率では側面投影で刺入点が翼简に近ず く程良いのに反し正円管到迋率逆に不良になる事が分 る. 以上の如き解剖統計学的根拠から私は前术せるよう
な刺入条件に加えて刺入点, 刺入方法を改良せる私の Ostwlat 改良法により先ず翼窝内への刺入を行つてか ら更に引き続きその針を正円孔部へ到達させる方法を案 出したので刺入方法の項に和いて述べる事にする.

かくして考究改良せる私の正円孔部上䫇神経伝達麻㱸 法は次の如きものである.

VIII 刺入方法

(1) 先ず助手に術側の口角部より扁平鉤を口腔前庭で下 顎骨上行枝の直前に達する迄深く挿入し煩部を側上方に 育引させる．この際患者には凡そ示指を軽く啮む程度の 幅だけ開口を命ずれば咀啷符の弛緩をきたし煩部と上頡 霜橝突起間の視野が広くなり注射針を刺入し易くなる。 (2) 次に口腔前庭部殊飞上顎結節後上方部周辺を広? Mercurochrom 液にて充分に消毒する.

(3) 上顎結節後上方部を $0.5 \%$ Novocain 液にて注射麻 酔を施こす

(4) 黒須氏上頡洞粘膜剝離子の短く強く等曲せる方で （黒須氏刋離子でなく適当なるのを使用してもよい）上 顎結節後端部を探ぐり，これに引つかけるようにして剥 離子尖端部をできるだけ頭蓋中心部方向に圧し同時くで

No. 1

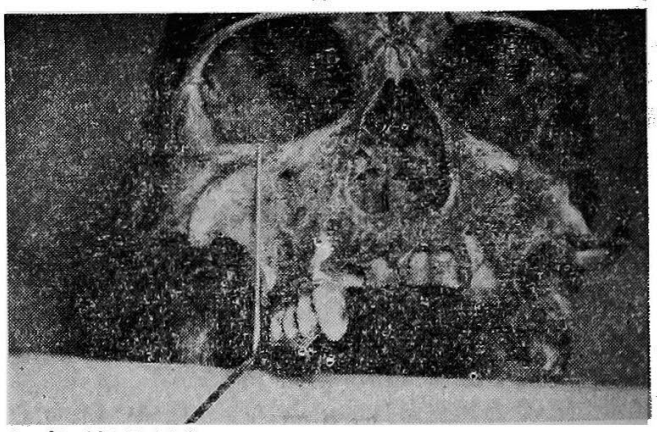

眼窠下縁最低点より同㑡の上顎第 2 小曰畨咬合面迄 の距離を刺入深度として予测する（目測）

No. 2

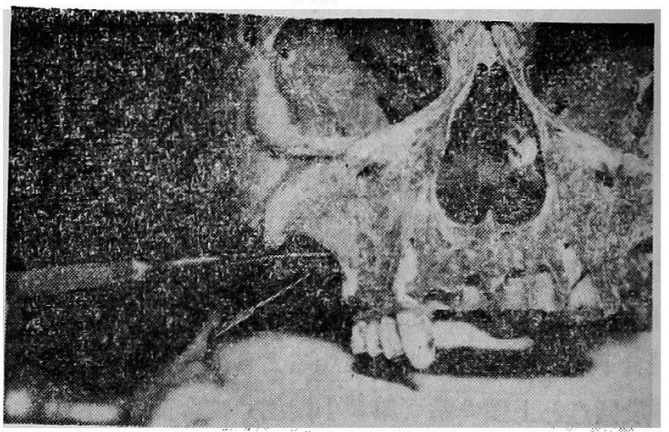


No. 3 (No. 2 の側面)

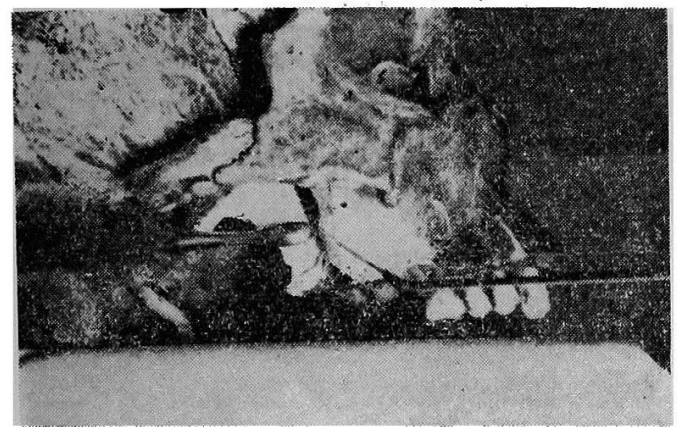

尖端藇曲せる Sonde で上第結節後端のできるだけ Fossa に近い上方部を探り刺入点と与る

刺入点において, 刺入針の屈曲部 (ab)を䊩槽縁に 対して斜めに制入する

No. 4
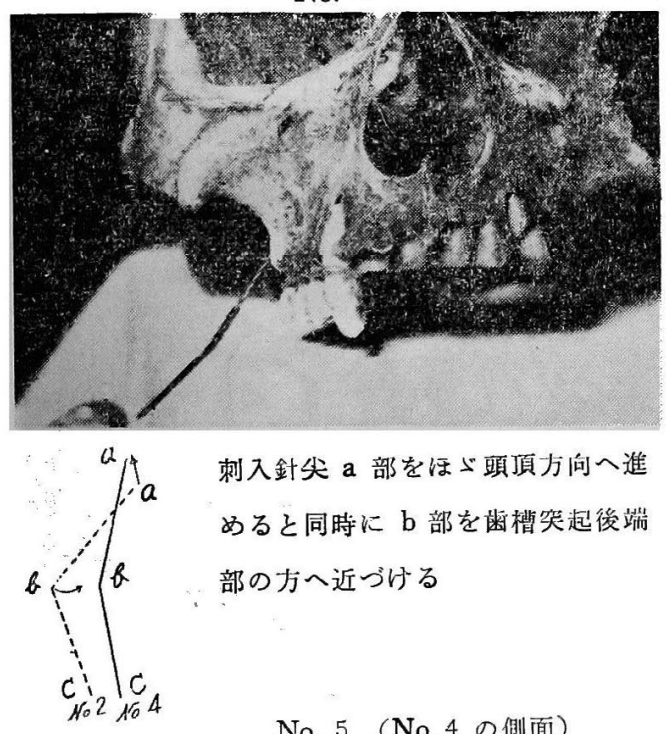

No. 5 (No. 4 の侧面)
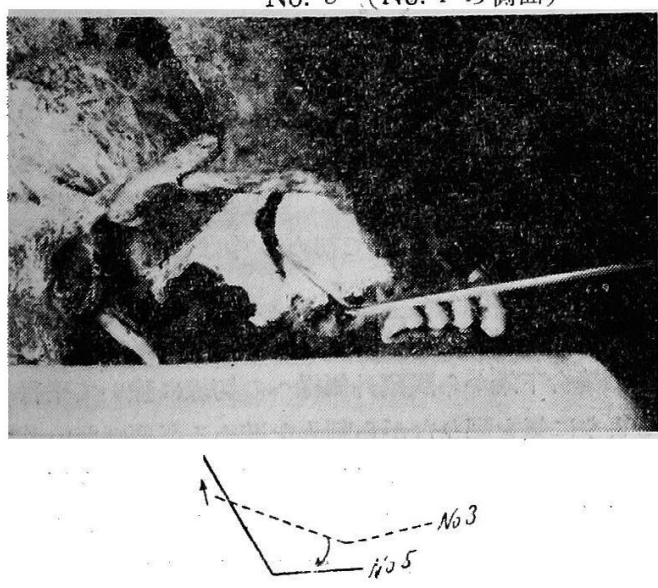

きるだけ上方部の粘膜移行部附近に位置せしめる，この ようにすると剝離子尖端は上顎骨と巽写起との境界部で しかも翼窝入口部に近い点を占めることになる。なお上 㖽結節の発育が悪くて後端の境界の不明瞭な場合には乎 指による触䛦で容易に判断することができる.

(5)この剥離子の豯曲せる尖端部の位置を刺入点之決め る.

(6)この刺入点より翼窩へ到達せしめる迄の刺入針の操 作を図 No.1〜No.7 に示す（第 10 図参照).

No. 6

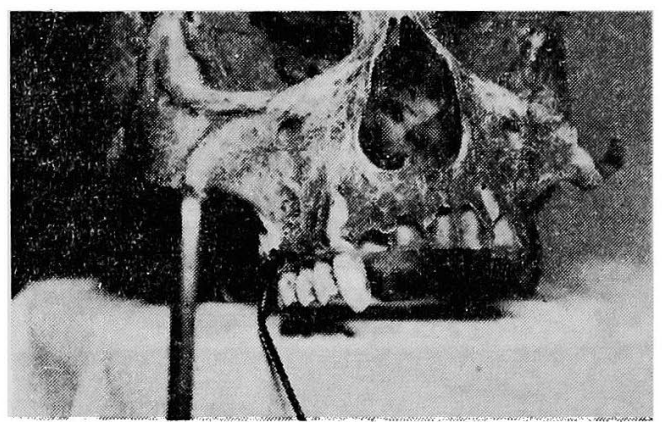

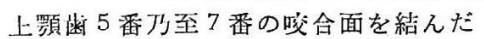
維の後方延長線を基準にして計測し刺 入距離が No. 1 に示した予测深度に 迄達すれば制入針尖端は Fossa 内に ある若し子测深度に迄刺入できずに途 中骨に突き当たれば針尖を前後左右に 少しつう移動せしめて予测梁度に迄刺

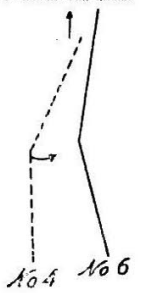

入する．そして歯槽突起後端と口蓋骨踓体突起との境 界部へ刺入針のb部を括しあて正中面に対する刺入针 の角度が 4.5〜13 度位になるようにする

No. 7 (No. 6 の側面)
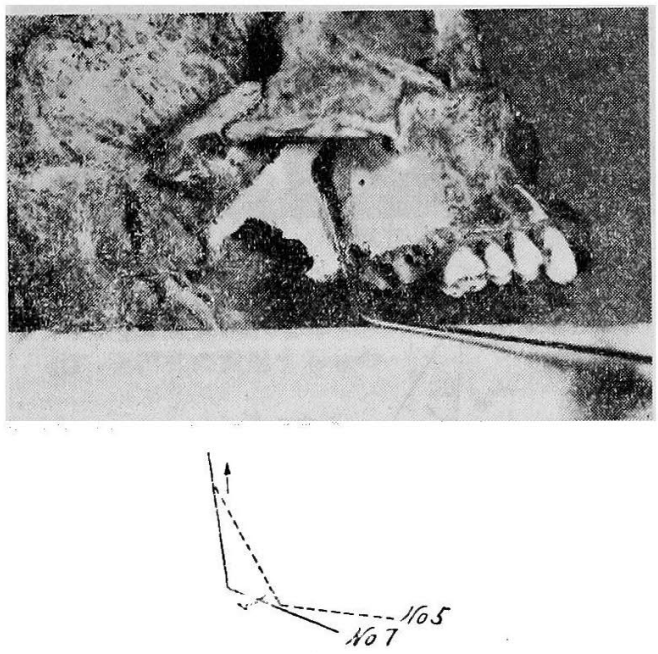
第 10 図

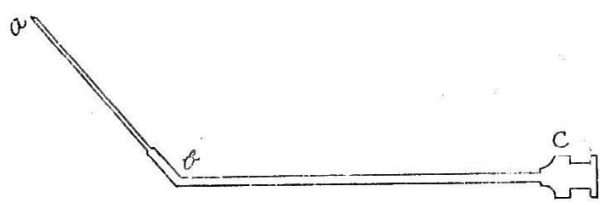

No. 8
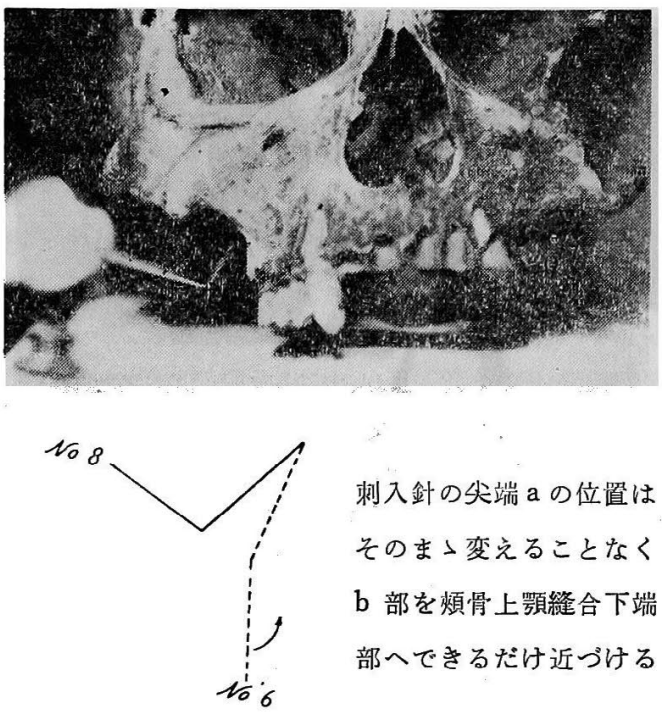

刺入針の处端 a の位置は そのま〉変えることなく b 部を煩骨上箱維合下端 部へできるたけ近づける

No. 9 (No. 8 の側面)
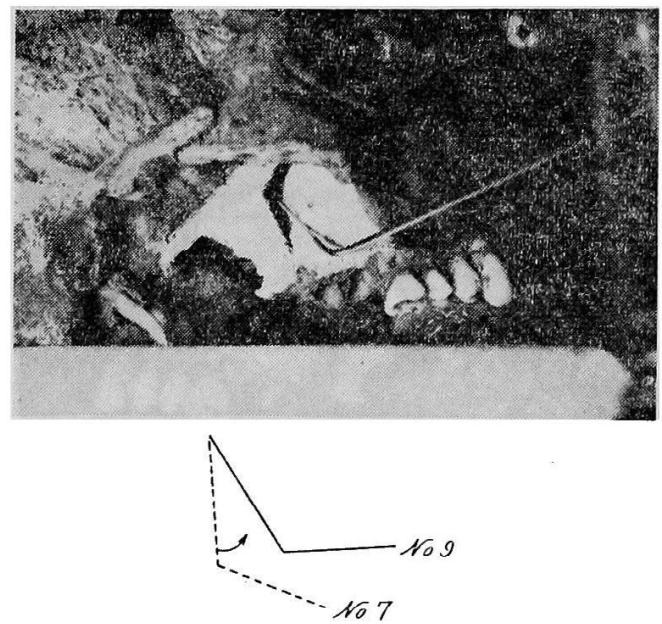

こつで注意することは最初の刺入角度がどうあろらと も刺入の途中より徐々に正中面に対する刺入角变を小さ くしてゆき予測梁变に迄刺入し終つた時に刺入針の（b)
No. 10

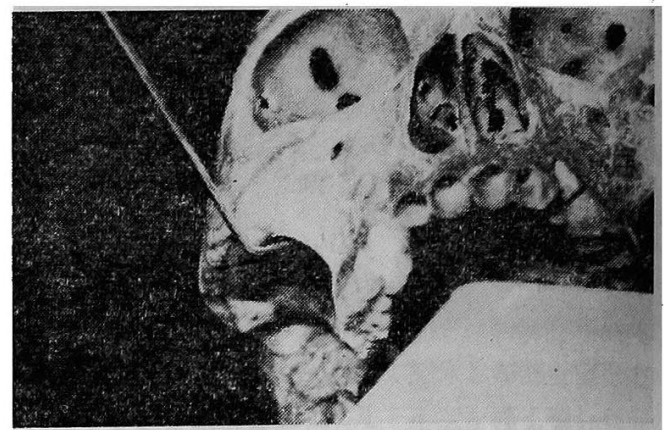

刺入針 (ab 部) を Foramen rotundum 方向へ 進める

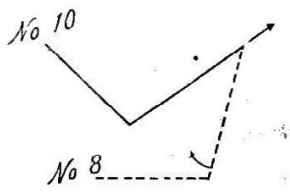

No. 11 (No. 10 の側面)

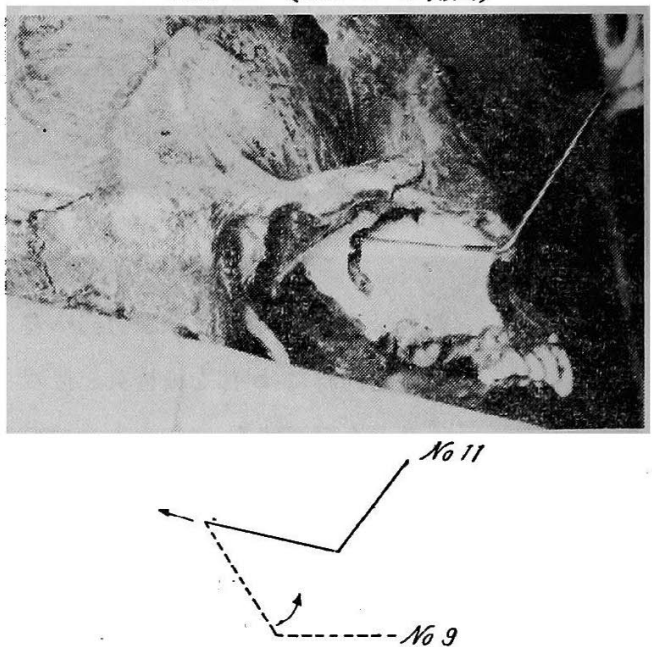

部（第 10 図参照）を霆槽突起後端部と 翼突起との境界 部（実際は雪槽突起 後端部と口蓋骨錐体突起との境界 部) に压し当て〉みて第 4 表, 5 表の 角度内（大略 4.5 〜13 度)にある事が必要で初めの 中はこの 角度を大き くし勝ちのため象角失敗する。

私のこの改良法は第 4 図及び第 3 表で示したよらに煩 骨上顎縫合下端から眼窠外側縁への切線に強いて平行に なるよらに気を配りながら刺入を進める必要はないが刺 入前に凡その見当をつけておき正面より見て上内側方向 に注射針を推し進めるよらにすると殊に enge Fossa の場合に効果的である、そして正中面に対する最初の刺 入角度は大きいが（但し刺入終了時に和ける刺入角安に 
No. 12
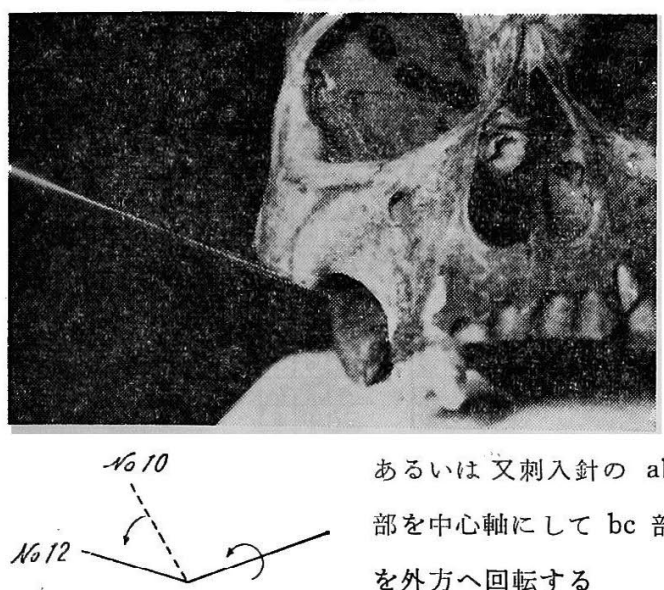

あるいは文刺入針の $\mathrm{ab}$ 部を中心斬にして bc 部 を外方へ回転する

No. 13 (No. 12 の側面)
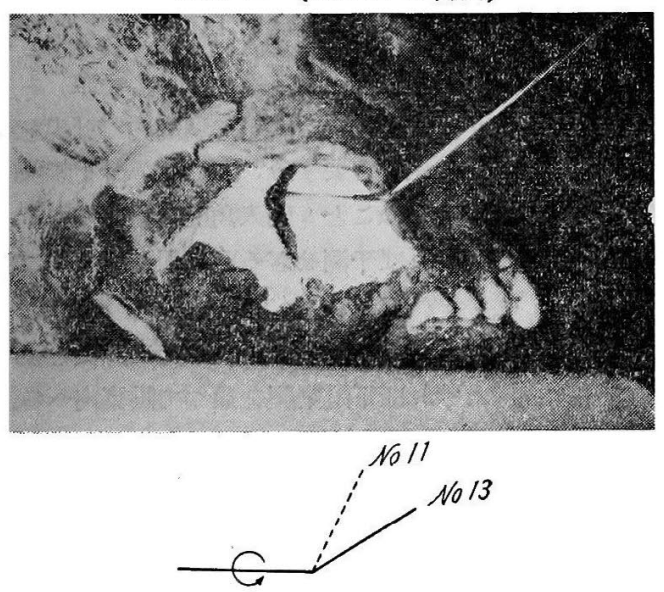

は注意必要) Arteria palatina descendens を損傷する

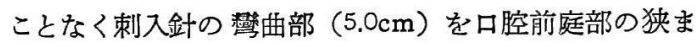
い場所において目標たる翼窝へ向けて容易に刺入せしぬ 得る方法である.

(7) 以上の操作で刺入梁度が予測深度に達すれば針尖は 翼窩内にあつて上顎神経に直達乃至は至近距離にある. しかしながら刺入針が途中でつかえて予測深度に迄刺入 できない場合には刺入針を前後左右に移動せしめて是が 非でもこの距離になるように刺入することが必要である (但し刺入終了時に执ける刺入角度に注意).

(8) 次に翼窝内に達した刺入洤尖を正円孔部へ到達せし める操作を図 No.8〜No.15 に示す (第10 図参照).

この刺入法を晒頭蓋骨で実験した場合の成績を第 14 表に示す：又この法を臨床的に用いて得た麻酔成清を第 15 表に示寸，な技用せる薬方は $2 \%$ Xylocaine 溶液
No. 14

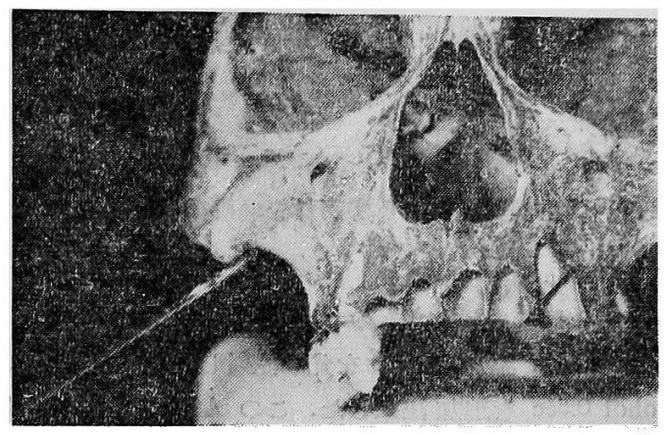

刺入針 ( $\mathrm{ad}$ 部) を

Foramen rotundum

方向へ進める

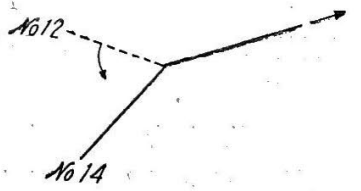

No. 15 (No. 14 の側面)
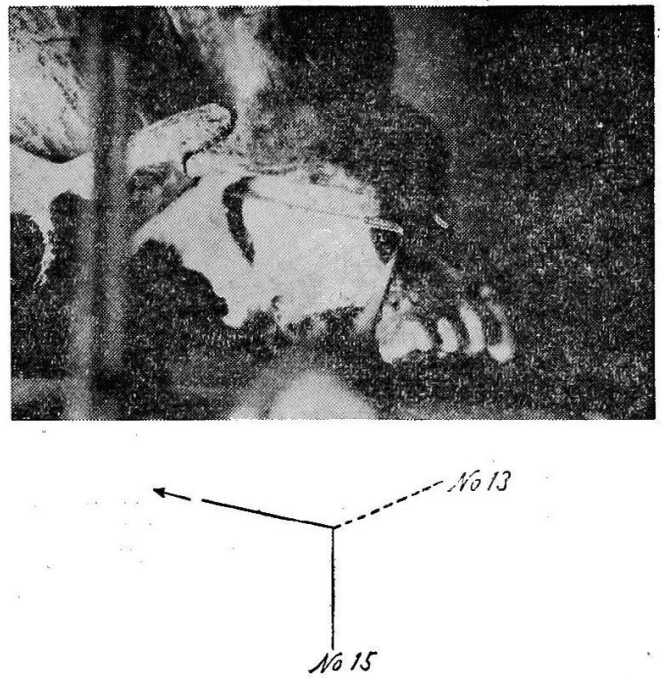

第 14 表

私の上記の刺入法による晒頭蓋骨 25 例 50 侧に特ける 正円孔到達率

(1) 正円孔に到達するもの $\mid \begin{aligned} & \text { 右 } \mid \text { 左 } \mid \\ & 23|24|\end{aligned}$

(2) 正円孔入口部に殆んど接して到達するもの 右左

（性別年令不問，但乙乳，幼，小児の標本は除外）

(2) は正円孔に到達するものとして一向に差し支え ない位置に針尖が達しているが敢えて放密に区 分した 
第 15 表 嫲 酔 効 果

$\begin{array}{ccrc}\text { 效果 } & \text { 症 例 } & \text { 該当例数 } & \text { 症例百分率 } \\ (\mathrm{H}) & 80 \text { 例 } & 8 \text { 例 } & 26.66 \% \\ (++) & 30 \text { 例 } & 12 \text { 例 } & 40.00 \% \\ (+) & 30 \text { 例 } & 9 \text { 例 } & 30.00 \% \\ (-) & 30 \text { 例 } & 1 \text { 例 } & 3.33 \%\end{array}$

（H）上顎洞のみならず洞外迄麻䣷奻果ありしもの

(H) 上顎洞全然無痽

(十）上類洞疼痛ありしもの

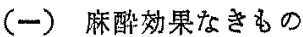

(Adrenalin 添加) 5.0cc 先す注射し, 次K $80 \%$ Alkohol 0.5cc を追加注入した. この Alkohol 注射炕就 いては 1903 年 Schlösser が Trigeminusneuralgie の 治療目的に 70 80\% Alkohol を使用してょり Ostwalt, Offerhaus, H. Braun 等が相次いで施行したも のであるが私の場合 Alkohol の追加注射性 小生洗が口 腔内注射法のため少しでも感染を予防する意味之麻酥 時間を延長させて少しでも患者の術後の苦痛を除くため に行つたので手術時の麻䤃に対してはXylocaine 溶液 (Adrenalin 添加)のみで充分効果的で Alkohol の追 加注射は敢えて必要でなく文献によれば万一譟つて不必 嬖な神経に Alkohol 注射を行克ば思わ婒害を招くこ とああり得ることを附記し和く。

麻酷効果炕就いて

(の)術側上口唇のシビレ感, 厚ぼつたくなつた感じ、”

2) 術側上罘歯の咬合時虚脱感, 異常感.

(3) 術倒鼻内下甲介粘膜の無痛感.

以上が唯認され】ば麻醒効果は充分と考克てよい。 刺入失敗の種々

(1) 刺入角度が大き過ざたつめに針尖が蝶形骨体あるい

は Foramen pterygopalatinum へ向つている場合.

(2) 刺入检が途中で引つからつて予測梁度に達しない埸 合.

以上(1)(2の場合には刺入方向を前後左右汇少しつ」変 えてみる、場合により改めて刺入し直す（刺入点を少し 〈前方移す)

(3) 翼䆟の横径が極端に 狭い enge Fossa の揚合，刺 入困難乃至失敗に終ることがある（Fossa 横径のData を第 16 表に示す).

\section{俱刺入に上る危険}

(1) 私の刺入法で刺入針の位賈を Matas-Braun, Sicher

Blumental 法等のように針尖分 後上万に向う位臂に直 してから正円孔に向けて針を進める際に頭蓋内に誤刺入 せぬ上らに注意すること(第 12 表参照)。

(2) 眼巢下緑最低点と上顎籍 2 小臼歯咬合面間の予測距

\section{第 16 表}

鸠頭蓋骨により Fossa 横径を計测した結果次の如し (単位 $\mathrm{mm}$ ) (各㑡每に横径の最大幅を求めた) O印は enge Fossa 右 23 左 30

\begin{tabular}{|c|c|c|c|c|c|c|c|c|}
\hline 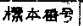 & 左 & 深 & 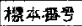 & 湮 & 右 & 㔍 4 本畨号 & 左 & 右 \\
\hline 1 & (a) & 6 & 18 & (3) & (2) & 35 & (5) & 6 \\
\hline 2 & 7 & 10 & $\overline{C y}$ & 6.5 & 7 & 36 & (4) & (4) \\
\hline 3 & 6 & 7 & 20 & (4) & 7 & 37 & 6 & 7 \\
\hline 4 & (2) & (2) & 27 & 5.5 & 6 & 38 & 6 & 7 \\
\hline 5 & 0 & (6) & 22 & 7 & 7,5 & 39 & (2) & (4) \\
\hline 6 & 5.5 & 7 & 23 & 6 & 6.5 & 40 & (3) & (1) \\
\hline 7 & (3) & (4) & 24 & 6 & $g .5$ & 41 & (3) & 6 \\
\hline 8 & (5) & 0 & 25 & 6 & 7 & 42 & 5.5 & 5.5 \\
\hline 9 & (3) & (6) & 26 & 7 & 7.5 & 43 & (6) & 6 \\
\hline 10 & (3) & (2) & 27 & (3) & 6 & 44 & (3) & (4) \\
\hline 11 & 6 & 6 & 28 & (4) & 5.5 & 45 & (2)! & (1) \\
\hline 12 & 65 & 6 & 29 & (6) & (3) & 46 & 6 & 6 \\
\hline 13 & (9) & 0 & 30 & (4) & (4) & 47 & (2) & 7 \\
\hline 14 & (4) & (3) & 31 & 6 & (6) & 48 & $(9)$ & (4) \\
\hline 15 & 7 & 6.6 & 32 & (4) & 8 & $d E$ & 3 & (5) \\
\hline 16 & (4) & (6) & 33 & (4) & (5) & sol & 6 & 6 \\
\hline 17 & 6 & 8 & 34 & (3) & (4) & & & \\
\hline
\end{tabular}

離は必ずしも正円孔下緑に相当する高さから上颚迷5番， 7 番の咬合面を結んだ線までの剌入距離に一致せずこれ より長い場合も短い場合もある(第9，10 表参照) それ 故予則距離の方が大きい場合が問題で翼墭内で針尖を移 動ざせるには䋖心の注意を要する。即っ刺入針を無謀化 上下動殊に上万に進め妨とと刺入角度を常に小さくす るように心馝けていれば予測せざる副作用を防せぐこと ができる.

(3) 上䫑結節後端上部上りの刺入であるため針尖を極端 に前上方に向けなければ下眼巢銐を通つて眼窠内への誤 刺入は防け゚る。

(4) 刺入角度に注意すれば Arteria palatina descendens を損傷することなく文乱暴な刺入を行わ限りは刺入途 中で翼㷎の内外汇おける不測の提傷出血をきたすことは 殆んどない。

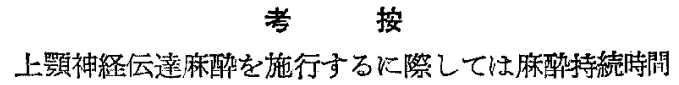
をできるだけ長く保つため及び完全麻醉效果を挙げるた めに Fossa 内に执いて正円孔直前文は正円管部に和斿 る神経䩗内注射を行うことが望をしいが，このことは往 来画角困難視される傾向にあつた．その理由は次のよう である，即ち正门孔部へ刺入針尖を到達させるためには 解剖学的にみて必ず Fossaを通ら权げならないが Fossa への刺入を困難ならしめる解剖学的諸要素としてTuber maxillae, enge Fossa, Tuberculum spinosum, Spina pterygoidea anterior がある. Spina pteygoidea ant. の発現率は 4〜6\%で低率のため㱠んど考慮する必要は 無いが Tuber maxillae は刺入の難易汇関する点ては 第1であり，又 enge Fossa は日本人では 53.3 69,2\% 
と高率である。（野村）

Tuberculum spinosum の出現率は 30.8〜71\% （野 村)で Fossa の上おより刺入する場合に影䇾がある。

次に従来の各泆の Fossa 及び正円管刺入率に 就いて 愉䛴してみると

(1) Härtel 法引晒骨 Fossa 及び正円管制入率は92,1 〜 100\% (野村) で優れているが下眼窠裂の续小，强度 の屈曲例では刺入不可能であり，刺入針の方向が正管 軸に平行である点は有利だが(野村)臨床的には下腿窼裂 に沿つて刺入針を進める際にその方向が少しく横にずれ ても佂つかつつたり文刺入針を余り上，下，左，右に移 動させて探ぐることは経腿巢法であるために副損賃上い ら点からら躊躇させられる。

(2) 煩骨及び顂骨弓上縁より刺入を行う Payr 及び Offerhaus 法は上方より Fossa へ刺入するため Crista infratemporalis の下垂例, enge Fossa 友び Tuberculum spinosum の発達している場合に 影響されるが栖 骨 Fossa 刺入率は夫々 31.6〜69.2\%，25.8〜53.7\%（野 村）と低率でありその上正円管に直達寸るものがない，

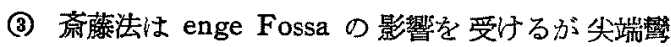
曲針を使用することにより Tuber maxillae による 障 客を避けてる泉い万法である。しかし weite Fossa 例

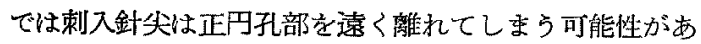
り仮令氏の术べる如く骨膜下に神経への浸潤麻斩が行わ れるにしても正円孔部乃至はその自前に和ける神経䩗内

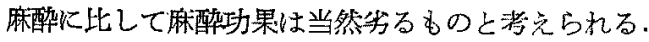

(4) Matas-Braun 矤は Tuber maxillae $の$ 影響を最 も受け Sicher, Blumental 法はこれを避けるために刺 入点を後万部に求めてるので野村の統計による晒婴 Fossa 刺入率は夫ん80.96〜92.3\%，92.3〜100\%，96.7〜 100\%と刺入点が Fossa 一近つく程良くなる加，正忺管 到造率は 79.37〜93.31\%, 69.2 84.6\%，38.3〜46.2\% と

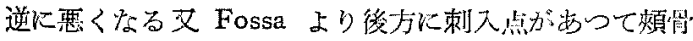
弓下緑上り刺入を行ら Offerhaus 江传 Fossa 刺入率山 84.6〜96.7\% であるが Grenzleiste 即ら，Fossa 入口 部の後縁が堤状に 邪魔して Fossa の後上方外側寄りの 凹陷部にある正円孔部人刺入針尖が到進しない，enge Fossa の影響保各法共避けられない。

(5) Ostwalt 法は enge Fossa の影澺を受けるが Tuber maxillae, Tuberculum spinosum Kよる影響车殆 んど受けないため (Tuber maxillae が後うへ特に膨隆 してる場合には影響される）晒骨·Fossa剌入染は 100\%

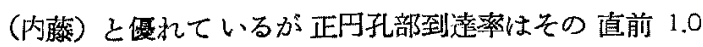

$\mathrm{mm}$ に針尖が到達するるのを含めて $29.7 \%$ (内藤) と 务つている．野村第1法はこの方法と大同小異で前者は 口腔内注射法犬゙が後者は顔面皮䟥上から刺入を行ら点が 異つている。

なホこの方法では刺入点と正円孔部を結んだ線の延長 線上に視神経が存在するので無謀に注射針を澡部へ進め ることは位険である。

(6) Hofer 法恓胃 Fossa 刺入率は 76.2〜61.5\%（野 村）で顿るが口蓋管の狭小及び屈曲の甚しい煬合に刺入 不问能であり，Fossa へ刺入できた場侖でる必ずしも正 円孔部へ針尖が 到造しない，正管到造珤は 53.9〜30.8 $\%$ (野村)である。

(7) 野村笨 2 法は enge Fossa の影響は受けるが Tuber maxillae による影響は少くて，氏の云ら外側三角 内に Matas-Braun, Sicher, Blumental, 野㤔第 1 法の 各刺入点が含玉れるため集中注射法の可能な非常に良い 方㳂であり，民炕よる磨酷成結は100\%である。

一般に Fossa は上下に長く横が短くそして上部が広 く下方に銧角の頂点を有するほら逆三角形の形状をして 沶り鋭角の 2 等分線を縱軸, 底辺を横軸と仮定して従来 報告された諸研究者の刺入力法を刺入方向によつて分村 ると次のようになる。

(a) Fossa の横軸方向より刺入を行う方法としては眼

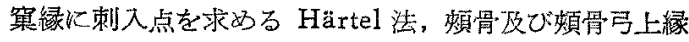
よりする Payr, Offerhaus 法及上顎骨の 媔学突起根部 を刺入点とする斎藤法，煩骨及び煩骨弓下縁より行う Matas-Braun, Sicher, Blumental, Offehaus 法がある.

(b) Fossa の縦軸力向へ下少より刺大を行う万法とし ては Ostwalt 法, 野村兴 I 法, Hofer 法がある。

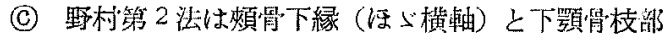

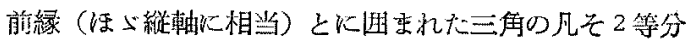
線上以刺入点が晾る。

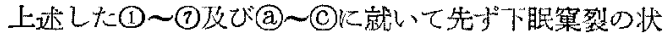
態によって山 Fossa 並びに汇山孔部への刺入の全く不 可能な Härtel 法を除外して检討してみると Fossa 刺 大率は私の仮定した Fossa の縦軦力向へ下方上り剌大 を行ら Ostwalt 法紧最優机ているが，正円管到達率

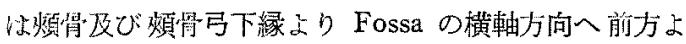

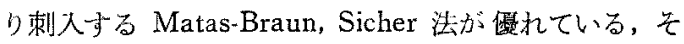
小故に Ostwalt, Matas-Braun，あるいは Sicher 法を 連続的に用いることの可能なう法，例汽ば野村第2 法が 凩西兑成綘の良いことは当然亡云える。

次に私の方法であるが，上述の観点からして私の考按 
せる注射針を用いて各症例语に眼䆵下縁最低点より同

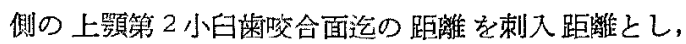
Ostwalt 法を改良せる私の方法により視神経損傷や頭蓋 内䛊刺入を起さずに確夷に針尖を先つ Fossa 内に和い

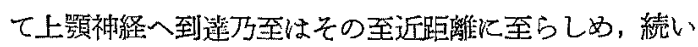
て刺入針の方向を Matas-Braun, Sicher, Blumental 等の剌入厅向に迄移動して正円孔部へ針尖を到達せしめ る万法で, 他の力法同様 enge Fossa の影餢は受けるが 最初加ら Tuber maxillae に邪魔されることが少く，

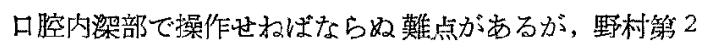
洗に比して刺入点が目標たる正円孔部により近いため, 刺入距離が短く，従つて針尖で Fossa を探ることも容 易であり，刺入針の腰の強さも私が試作したものを用い れば充分である。

しふしながら臨床的に私の方法の麻醣成結をみると， 完全麻酔奻果杂示吉例は観察例数 40 例で 26,66\%，野村 符 1 法 (60例, 18.33\%), 䬔藤筧法 (158 例 13,29\%),

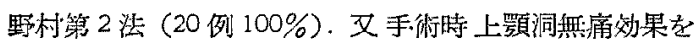
示せる6のは私の方法 40\%，野村筝 I 法 $(50 \%)$, 斎藤 法 $(54.43 \%)$. 上顎洞に一部落痛ありし6の私の方法 30 $\%$ ，野村第 1 法 (18.33\%)，亩藤法 (27.83\%)，無効例 は私の方法 $(3.33 \%)$, 野村第1法 $(13.34 \%)$, 斎藤法 (4.43\%)，野村第 2 法（0\%）で期待した程の成績を得 られなからた，その最大の理由としては enge Fossa 例 て㞗ふ刺入針の位置を Ostwalt の刺入力向から Matas. Braun, Sicher, Blumental 筂の方向へ变党ること, 即

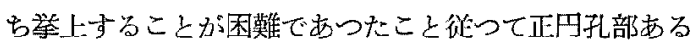
い坆の近くでの神経鞘内注射が不充分でありたり，あ るいは及袖経周辺への浸潤麻䁌に終つたことが考えられ

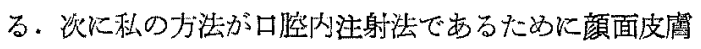
上より行ら注射法汇比して刺入点よりの感染の危険性か 多分にあるといらことが业然考充られるが, 80\% Alkohol $0.5 \mathrm{cc}$ を $2 \%$ Xylocaine 液注射後に迫加注入する という方法を榙みた㳩の70 側手術例の経験よりして执 生凧等を使用しなくても完全に感染㧍ができるすのと 信ずる，そして神経䩗内への 80\% Alkohol の注射は術 後の文術後処置の祭の昸痛から患者を救らこと大である が術側の知覚鈍麻が長期間残る欠点がある。

\section{結語}

私は性別，年令を問わずに先づ唒頭蓋骨に就いて Fossa 並びに正円孔部刺入儿必要な計测を行い，その紕

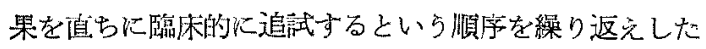
絬果，第1段階としてOstwalt 治を玫良せ西私の確すな
るFossa 刺入潜に上り, Fossa 内に打いて上顎神絽に 直達乃至はその至近距離へ針尖を到達せしめ，続いて第 2 段階として Matas-Braun, Sicher, Blumental 法等の 刺入方向に运刺入針を挙上することにより，正円孔部に

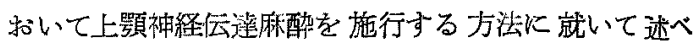
た。

\section{文献}

1) Braun, H; Über die Lokalanästhesie bei Operationen im Trigeminusgebiet (Deutsche Zeitschr, f. Chir. Bd. II. 1911). 2) Braun, H.: Über die Behandlung von Neuralgien des 2. und 3 , Trigeminusastes mit Alkoholinjektionen (Deutsche med. Wochenschr. Bd. 52, 1911). $\quad$ 3) Härtel, F.: Die Leitungsanästhesie und Injehtionsbekandbung des Ganlion Gasseri und der Trigeminus stämme (Arch' f. klin. Chir. Bd. 100, 1912). 4) Offerhaus: Die Technik der Injeltion in die Trigeminustämme und in das Ganglion Gasseri (Arch. f. klin. Chir. Bd. 92, 1910). 5) Offerhaus: Schmerzlose Operatio nen im Gebiet des Gesichtsschädels und Mundes unter Leitungsanästhesie (Deutsche med Wochen schr. Bd. 33, 1910). 6) Ostwalt, $F .:$ Über tiefe Alkohol-Cocain-oder Alkohol-Stowain-Injektionen bei Trigeminus-und anderen Neuralgien (Berliner klin Wochenschr. Nr. 1, 1906). 7) Blumental: Zur Lokalanästhesie der Oberkieferorperationen (Berliner klin. Wochenschr. Bd. 11, 1914). 7) 高木栁 三：高木局所解剖学，第6 版.9) 金于五之助：日 本人体解剖学，1 $\sim 3$ 巻，第 3 版，10) 野村俊伍：日 耳嶨学会報, 55 巻 10,11号. 11) 窟藤寬：日耳畋 学会報，60巻 11 号. 12) 弓倉慗家：歯㳆麻醉学,

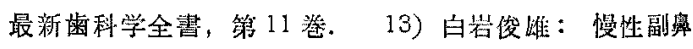
腔炎手術時の麻酔（日本医事新敨，(No. 1791)。14)

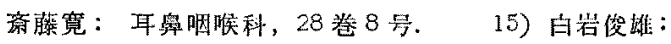

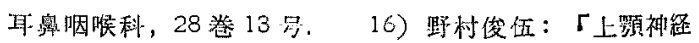

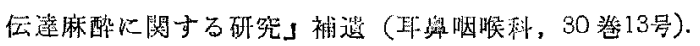
17) 西成甫：人体獬剖図钫，第 1 巻.

擱筆に当り，御指導，御校閲を賜つた恩師西端臨 一教授に潇しんで感謝の意を表します

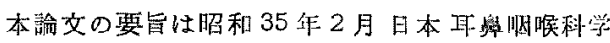
会関東地厅会第 367 回例会に抋いて報告した。

（傆乘到着=䀡和 35.8 .19 日） 